NBER WORKING PAPER SERIES

\title{
CITIES AND GROWTH: THEORY AND \\ EVIDENCE FROM FRANCE AND JAPAN
}

\author{
Jonathan Eaton \\ Zvi Eckstein
}

Working Paper No. 4612

\author{
NATIONAL BUREAU OF ECONOMIC RESEARCH \\ 1050 Massachusetts Avenue \\ Cambridge, MA 02138 \\ January, 1994
}

We thank Paul Beaudry, David Canning, Sam Kortum, Ed Prescoth, Victor Rios-Rull, and participants at presentations at Universitat Pompeu Fabra and Harvard University for constructive comments, M. Minni of INSEE for his helpfulness in providing data on French agglomerations, and Aditya Bhattacharjea, Yuval Nachtom, and Akiko Tamura for their excellent research assistance. Akiko Tamura constructed population data for Japanese urban agglomerations from census figures on the population of Japanese cities. This paper is part of NBER's research program in International Trade and Investment. Any opinions expressed are those of the authors and not those of the National Bureau of Economic Research. 
NBER Working Paper \#4612

January 1994

\title{
CITIES AND GROWTH: THEORY AND \\ EVIDENCE FROM FRANCE AND JAPAN
}

\begin{abstract}
The relative distribution of the populations of the top 40 urban areas of France and Japan remained very constant during these countries' periods of industrialization and urbanization. Moreover, projection of their future distributions based on past growth indicates that their sizedistributions in steady state will not differ essentially from what they have been historically. Urbanization consequently appears to have taken the form of the parallel growth of cities, rather than of convergence to an optimal city size or of the divergent growth of the largest cities. We develop a model of urbanization and growth based on the accumulation of human capital consistent with these observations. Our model predicts that larger cities will have higher levels of human capital, higher rents, and higher wages per worker, even though workers are homogeneous and free to migrate between cities. Cities grow at a common growth rate, with relative city size depending upon the environment that they provide for learning.
\end{abstract}

Jonathan Eaton

Department of Economics

Boston University

270 Bay State Road

Boston, MA 02215

and NBER
Zvi Eckstein

Tel-Aviv University

Ramat Aviv

Tel Aviv 69978

ISRAEL 


\title{
CITIES AND GROUTH: THEORY AND EVIDENCE FROY FRANCE AND JAPAN
}

\author{
Jonathan Eaton and Zvi Eckstein
}

December 1993

\section{INTRODUCTION}

A basic aspect of economic development is the movement of population from the countryside to cities. 1 In this paper we consider the particular cases of France between 1876 and 1990 and Japan between 1925 and 1985, both of which experienced substantially increased urbanization during these periods of industrialization. ${ }^{2}$

We consider the further issue of whether urbanization took the form of: (1) an increase in the population of larger cities relative to other cities ("divergent growth"), (2) the growth of smaller cities relative to larger cities ("convergent growth"), or (3) similar growth rates across cities of different sizes ("parallel growth"). Ve find that the evidence rejects the first hypotheses: Urbanization took the form of similar grouth rates across cities of different sizes (with only slightly faster growth of large cities in

IXuznets' (1966) historical data document the increased share of population living in urban areas during the economic development of a number of rich nations. Chenery and Syrquin's (1980)'cross-sectional evidence shows that the share of a nation's population that lives in cities rises with its per capita GNP.

2Between 1876 and 1990 the population of France grew from 36.9 million to 55.8 million, while the agglomeration of Paris grew from 2.6 million to 9.3 million. Between 1925 and $1985 \mathrm{Japan}$ grew from 59.7 to $122.6 \mathrm{mill}$ ion people, while metropolitan Tokyo grew from 6.5 million to 26.5 million. Hence ve are considering each country for a period in which the total population roughly doubled, while the population of the largest urban areas (as well as the other urban areas in our sample) approximately quadrupled. 
Japan) .

Ve then develop a model of growth and urbanization consistent with this finding. Ve adopt a model of urban development in which urban growth is driven by the acquisition of human capital. ${ }^{3}$ Ve choose this approach because of the emphasis that a number of observers of urban development have placed on the role of human capital in the functioning of cities. 1 Lucas (1988), in particular, specifically relates what his model identifies as the driving process of economic growth, the acquisition of knowledge and the externalities associated with it, to the forces that lead to the development of cities:

It seems to me that the 'force' we need to postulate to account for the central role of cities in economic life is of exactly the same character as the 'external human capital' I have postulated as a force to account for certain features of aggregate development. (1988, pp. 38-39)

Nevertheless, this literature has so far not provided any formal link between the processes of economic growth and of urbanization.

Going back at least to Adam Smith, analysts have thought about economic growth in terms of nations. This focus may partly reflect the availability of data at that level. But nation states typically correspond to single legal jurisdictions and, as posited by Ricardo, may best correspond to the domain of

\footnotetext{
3Work on the determinants of economic growth has attempted to explain the secular growth of per capita GNP in terms of (i) physical capital investment (Solow, 1956, Romer, 1986), (ii) the accumulation of human capital (Uzawa, 1965, Lucas, 1988), (iii) product and process innovation (Inada, 1969, Grossman and Helpman, 1991), and (iv) learning by doing (Arrov, 1962, Young, 1991).

4See, for example, the discussions in Jacobs $(1969,1984)$, Henderson (1988), Rauch (1991), and Glaiser, et al. (1992). Much of the urban literature has focused on the development of cities that specialize in the production of particular commodities (as in Henderson, 1988). Our approach, in contrast, focuses on cities that need not be specialized, whose productivity derives from the interaction of individuals with complementary forms of knowledge.
} 
factor markets. For these reasons this choice of unit may be totally reasonable. Nevertheless, it remains an open question whether the driving forces of economic growth are primarily national in character, with the growth of cities following as a derivative, or whether the process of economic development can better be understood by focusing on some smaller unit, such as the city. The model ve develop in this paper allows us to distinguish between local and national sources of grouth.

Our purpose here is to review some issues raised by the role of urbanization in economic growth, to examine some evidence, and to provide a simple analytic framework to relate the process of urbanization to economic growth. Ve do so by integrating two branches of literature, that on the endogenous determinants of economic growth, in particular the Lucas (1988) model of human capital accumulation, and that on circular cities, developed by Iills (1967), Arnott (1979), Helpman and Pines (1980), and Henderson (1987, 1988), among others.

In Section II which follows we consider the basic empirical question of the extent to which the process of urbanization associated with development is primarily extensive, taking the form of the creation of new cities, or intensive, involving the growth of existing cities. Existing work on urbanization and growth (e.g., Miyao, 1987, Henderson, 1987), predicts that urbanization takes the form of the creation of new cities, whose size converges to an optimum city size.s Hére ve develop an alternative approach in which urbanization involves the parallel expansion of a given number of cities.

sHenderson's (1987) analysis relates new cities to new industries. The steady-state implication is that "the economy grows by churning out new cities at the rate of population growth." (p. 950). Glaiser et al. (1992), on the other hand, find that diversified cities tend to grow faster. 
The question is analogous to the issue of "convergence" in economic growth. The hypothesis that urbanization is primarily extensive implies that city sizes should "converge," i.e., initially smaller cities should grow faster than larger cities, Our alternative model implies "parallel growth," that is, population growth rates that are independent of initial size, with growth rates converging to a common value.

We examine this issue with data from 39 French urban areas (agglomerations) from 1876 to 1990 and for 40 Japanese urban areas for the period 1925 to 1985 . The French data provide striking evidence in favor of parallel growth: The size distribution of cities remains virtually unchanged throughout the period. Yoreover, we find little evidence either of "new" or of "dying" cities. Results for Japan also suggest evidence of parallel growth with some slight, statistically insignificant, additional concentration in large cities. In neither country do we find any support for the convergence or divergence hypothesis. ${ }^{8}$

We then develop, in Sections III, IV and V, a model of urbanization and growth consistent with the parallel steady-state growth of cities, but with possibly different short-term growth rates and changes in the ranking of individual cities.

Section III presents a static model of a city. Land is a factor of production, and total productivity within a city declines with the distance of

BThe notion that relative city size does not change even as urban populations grow relative to the population as a whole has an old tradition in the regional science literature. In particular, the "rank-order rule" asserts that the product of a city's population and its rank in population is constant across cities and time. Beckmann (1958), Rodwin (1970), and Henderson (1988) discuss the rule and its history. With the exception of the analysis in Henderson (1988), which concerns the growth of specialized cities, the rule does not appear to have played a role in current theories of urban growth. The rule does not appear to be mentioned, for example, in the Bandbook of Regional and Orban Bconomics (1987). 
production from the city center. This last assumption is meant to capture in a simple way the contribution of urban agglomeration and proximity to productivity.

In Section IV we make the model dynamic. We relate total factor productivity in a city to its average level of human capital, as in Lucas (1988). A basic characteristic of a city is the environment that it provides for acquiring human capital (which can either be city-specific or general in terms of its applicability). Cities are linked together in terms of how their human capital stocks contribute to learning, much as the human capital stocks of different countries jointly contribute to national pools of knowledge in Lucas (1993). The interaction of the human capital stocks of different cities implies that, in the long run, city populations will grow at common rates.

Vigration provides the link between the growth and distribution of human capital among cities and their relative populations. In Section $V$ we analyze migration between cities of different relative levels of human capital. The model implies that cities where time spent acquiring human capital is more productive will have larger populations, higher wages, higher land rents, and higher levels of human capital per vorker, correlations consistent with the data. ${ }^{7}$ In Section VI ve provide some concluding remarks.

\section{EVIDENCE ON DEVELOPIENT AND THE SIZE DISTRIBOTION OF CITIES}

We have already mentioned that economic growth and urbanization are very parallel processes. Ye now consider the question of how cities of different

We $f$ ind a correlation between city population and vages and population and price level in our French data. Rauch (1991) finds a significant positive correlation between levels of human capital and city size in U.S. cities. Henderson (1988) discusses other evidence on the correlation of education levels and city size. 
sizes grow during the process of development. One possibility is that urbanization occurs as nev cities develop, and as smaller cities catch up with larger ones, in which case the size distribution of cities vould become more even over time. At the other extreme, urbanization could take the form of the expansion of the largest cities, so that the size distribution vould become more unequal.

To examine this issue we look at historical data on urban agglomerations from France and Japan. We choose France for several reasons. First, since it is a high-income country we can observe the evolution of its urban structure during the process of industrialization. Second, it has constituted an intact nation-state more or less within its current borders throughout the industrial revolution. Third, its total land area was settled at the origin of the industrial revolution. Fourth, it is geographically large enough to contain a number of distinct, large metropolitan areas. 8 Japan shares the first three characteristics but not the fourth. However, we have constructed data on agglomerations for Japan that seem to be consistent for the period under consideration.

We have collected data on the population of 39 urban agglomerations in France for the years 1876, 1911, 1936, 1954, 1962, 1982 and 1990 (see Table A1). ${ }^{8}$ Our criterion for selection is a 1911 population of at least 50,000 inhabitants. Only two agglomerations (Grasse-Cannes-Antibes and Bethune) not in our sample rank among the top 35 cities in 1990 (rank 17 and 19) in 1990. The smallest agglomeration in our sample (Hagondage) ranks 50 in 1990 . Hence,

8Wile Great Britain shares the first three characteristics, because of its much greater population density, metropolitan areas tended to blend into each other during the process of urbanization. We could not find historical data based on definitions of urban areas that remained consistent during the period of interest.

'The data are from INSEE, Innuaire Statistique de la France, various issues. 
there are almost no new urban agglomerations since 1911 and no urban agglomeration has fallen drastically in its relative size, i.e., no city that was big (relatively) in 1911 has "died."10

For Japan we have organized data for the largest 40 agglomerations from 1925 to 1985 for every 5 years (see Table 12). The definition of each agglomeration is not trivial. An appendix explains how agglomerations vere defined and how the data vere constructed." Ve included all agglomerations that had a population of at least 250 thousands in 1965. As in France, only a few (3) agglomerations not in the sample became marginally larger than those in the sample by the end of the period. But there is no "nev" city in that every city in the top 30 cities in Japan in 1990 was in our sample. Similarly, none of the cities in the sample "died" in that none of the cities in the sample ranks below 50 in 1985 .

As we discussed in the introduction, the urban economics literature addresses the issue of new cities and the optimal size of a city (e.g., Henderson, 1988), both in static and dynamic contexts. The evidence from France and Japan is that there are no new cities. Even the tourist cities in France, which may be vieved as new, existed and had a moderate size by the beginning of the 19th century.

10yoreover, the two towns that did grow substantially faster than the other cities and became agglomerations that rank among the top 20 in France are tourist centers with a significant locational advantage. If the demand for leisure and tourism is highly income elastic then the substantial increase of French income per capita over the last 130 years can easily explain the high growth of these tro cities. Since our focus is on aggregate growth and the size distribution of cities that produce a common good, it seems reasonable to ignore those cities whose location led to higher growth due to a higher income elasticity of demand for their specialized product.

"The data are based on historical city population census data provided in Ianketsu Showa-kokusei-Soran, vol. 1, in turn based on data from the Statistics Bureau of the Management and Coordination Agency of the Japanese Government. Akiko Tamura aggregated the city population data into data for urban agglomerations. An appendix discusses agglomeration definitions and aggregation procedures. 
Lorenz Curves

Using our French and Japanese samples of agglomerations we computed the Lorenz curves for population for each year in our sample for France and every second year for Japan. These are displayed in Figures 1 and 2 and in Tables $A 3$ and $A 4$. The French data demonstrate starkly how the size distribution of cities has not changed noticeably during the most spectacular period of growth of population, movement of population from rural to urban areas, and growth of income per capita. While the population of Paris nearly quadrupled during this period (while that of France as a whole did not quite double) its share of the total population of our sample of cities remained stable at 40-43 percent from 1876 to 1990 . The change of ranking among the cities (up and down within the sample) is more frequent for small cities. That is, the relative size of a city in the sample is more stable among the largest cities.

The Japanese Lorenz curves show a slight movement towards less equal distribution of size. The share of the larger cities went up and, in particular, Tokyo's share increases for the whole population as vell as among the top cities. It is interesting to note that the Lorenz curve for France is the same as the Japanese Lorenz curves for the early years. Hence, the two countries, which are significantly different in their geographical structure, have a very similar size distribution of cities. 12

The stability of the Lorenz curves could be the consequence of any number of dynamic processes driving the population growth of individual cities. The most obvious possibility is that all cities on average grow at the same rate starting at different levels ("parallel growth"). Two possibilities are ruled

12The "rank-order rule" also implies stable Lorenz curves. However, this rule makes the largest city to be about $20 \%$ of the sample of 40 cities, while the largest city is in fact much bigger ( $30 \%$ for Japan and $40 \%$ for France). 
out, hovever. If there vere an upper bound on city size that was attained by any city in our sample then ve vould expect the initial level of population of the city to be negatively correlated with average growth rate ("convergence of size distribution"). The size distribution of cities vould then be getting more equal over time. On the other hand, if the growth rate of a city is positively correlated with its initial size ("divergence of size distribution") then we vould expect the Lorenz curves to exhibit increased inequality over time.

Figure 3 displays the French average annual growth rates of the cities from 1876 to 1990 and the initial level of each city in 1876. The regression line implies that there is no correlation between the initial size of the agglomeration and the growth rate during that period. (The slope coefficient is $-1 \times 10^{-6}$ with a S.E. of $1.56 \times 10^{-6}$.) Figure 4 presents the equivalent picture for the Japanese cities. Here, as vell, there is no obvious correlation between the initial level of population and its subsequent growth. The slope is positive but not significant $\left(1.3 \times 10^{-9}\right.$ with a S.E.of $\left..8 \times 10^{-9}\right)$. This result is consistent with stability of the Lorenz curves as well as with parallel growth. 13

Size and other Features

For France ve also have data on the average salary per full-time employee in each agglomeration in 1982 and 1989 (Table A5). A regression of vage income on population of the agglomeration yields a positive and significant coefficient for each year separately (see Table 1a). Furthermore, the

13The results in Figures 2 and 3 are similar to Barro's (1991) on the relationship between per-capita income growth and the initial level of income per capita in the Sumers and Heston (1991) country data. 
coefficients of the two years estimated separately turned out to be close. Hence, wages are higher in larger cities following a stable relationship. Table 1b reports the regression of the price of housing on city size, which indicates that larger cities have a higher cost of housing. ${ }^{14}$

\section{Bvolving Size Distributions}

Quah (1993) provides a statistical method to make further observations on the cross-section dynamics of relative levels and grovth rates of income per capita in terms of evolving distributions. Following Quah's procedure, we group the two samples of cities into 6 cells defined according to a division of population sizes relative to the average population for the respective period. To examine the sensitivity of the results to the particular cell division, we use different assignments, but we report only one division which is the same for both France and Japan and is reported as the row headings in Tables 2 and 3. (Alternative cell divisions provided very similar results.)

Our division classifies cities according to whether their population fell in the range: (1) less than .30 of the mean, (2) between .30 and .50 of the mean, (3) between .50 and .75 of the mean, etc. These tables show the frequency distribution and numbers corresponding to each cell. The stability of these distributions across time and the similarity between France and Japan is of course another manifestation of the observations we made about the Lorenz curves that we described above.

We define $F_{t}$ as a $6 x 1-v e c t o r$ indicating the frequency of cities in each cell at time $t$. We assume that $F$ evolves according to:

14The data for this regression are from 1982, and are available for only 20 agglomerations. 


$$
\begin{gathered}
-11- \\
F_{t+1}=\mathbf{Y} \mathbf{F}_{t}
\end{gathered}
$$

where $y$ is a $6 \times 6$ matrix mapping the assignment from period $t$ into an assignment the subsequent period. An element of this matrix denotes the probability with which a city initially in the cell corresponding to that column transits into the cell corresponding to that row. The s-period-ahead predictor for the distribution is thus:

$$
F_{t+s}=\mathbf{r}^{s} F_{t} \text {. }
$$

Taking $s$ to w ve can characterize the long run (ergodic) distribution of $F_{t}$, defined as $F_{\Phi}$ (if it exists and is unique).

Defining $\mathbf{u}_{i, i+1}$ as the actual transition matrix from period $i$ to period $i+1$, we have estimated the matrix $\mathbf{u}$ by computing the average $\mathbf{u}_{i, i+1}$ for all the periods in the sample. The estimated matrices for France and Japan are given in Tables 4 and 5 , respectively. The large values of the diagonal terms and the many low values and zeros of the off-diagonal terms of both matrices indicate high persistence. For France, diagonal terms tend to increase with relative size, indicating more persistence for larger cities. For Japan, the diagonal terms are higher for small and large cities than for medium-sized cities. Overall, the values on the diagonal are higher for Japan than for France and there are no off-diagonal têrms for the highest cell in the Japanese matrix. These results suggest that there is more persistence in the Japanese data, no movement in and out of the cell containing the largest 3 cities, and less movement among the smaller cities than is the case for France.

The ergodic probability distribution is estimated by taking the average 
of the implied ergodic distribution from each date in the sample using the estimated average period-to-period transition matrix. That is, using the estimated $Y$ we calculated $F^{\infty}$ by first calculating, for each year in the data:

$$
F_{i}^{\infty}=\mathbf{r}^{\infty} F_{i}
$$

and then estimated $F^{\infty}$ as the simple average of $F_{i}^{\infty}$. These values are reported in Tables 6 and 7 for France and Japan, respectively. Concentration of the frequencies around one would imply convergence to the mean. The results show no such convergence for either country. For France, about $90 \%$ of the cities will be below the average. Only few cities will be above the average size. About 59\% of the cities will be less than one half of the average size. The results for Japan are similar: $88 \%$ of the cities are below average and $75 \%$ are below one half of the average. Hence, the dispersion of population in Japan is expected to be less equal than that for France (as was also suggested by the movement of the Lorenz curves).

The predicted relative size of Paris will be smaller and there will be fewer cities that are large. That is, compared with the historic relative frequency for France, the ergodic frequency has more weight on the smaller cells. In 1990 the larger than average cities in France are about 15\% of the total and their share will drop to about 10\%. For Japan, as we explained above, there is almost no change at the top but a small increase in the share of the smaller cities relative to 1985 distribution.

Hence, the evidence rejects a divergence hypothesis and is consistent with parallel growth with a somewhat less disperse distribution for France. In particular, Paris and the other larger cities would be somewhat closer to the average size. Similarly Japan displays no evidence of convergence. In 
summary, the data support the view that a wide range of city sizes will persist.

\section{III. $\$ YODEL OF $\triangle$ CITY}

We now develop a model of a system of cities with features that reflect our empirical findings on the size distribution of French and Japanese cities, and correlations between city size and other city characteristics. Our theory has the implication that cities' populations converge to a common growth rate, with different relative populations. A city's relative size depends upon its productivity as a place to acquire human capital. In steady state, wages per worker are higher in larger cities because the level of human capital per vorker is higher. City populations adjust to remove any incentive to migrate.

Ve describe each of $\mathbf{K}$ individual cities in terms of a representative resident who lives, works, and learns in that city. We pursue our analysis in three steps. Step 1, presented below, describes the preferences and the static production technology for a typical city. Here we characterize the equilibrium relationships between wage, population, and city area implied by the maximization problem of the representative resident. 15 Step 2, undertaken is Section IV, considers human capital accumulation and growth in a typical city, again in terms of the maximization problem of the representative resident of that city, ignoring the possibility of migration. Here ve provide conditions for steady-state growth in the system of cities. Step 3 , discussed in Section $V$, treats the incentive for a representative resident to migrate, and its consequences for relative city size.

150ur static model of production takes much from the literature on circular cities. See, for example, Yills (1967), Helpman and Pines (1980), and Henderson (1987). 
Endowments and Tastes

The representative resident of each city supplies a unit of labor each period regardless of the wage. Residents are infinitely-lived (or behave dynastically), and maximizes an objective function:

$$
v_{0}=\int_{0}^{\infty} e^{-\rho t} \ln \left(c_{t}\right) d t \quad, \quad \rho \geq 0
$$

where $c_{t}$ is period $t$ consumption. Residents do not vorry about the amenities that different cities offer except as they affect income.

Techrology

To focus on the issues at hand, we assume that labor and land are the only factors of production. 10 These factors produce a single kind of output, which has a price one each period. Production is Cobb-Douglas in labor and land, with land having a share $\beta$. Total factor productivity in each city i is affected by a city-specific multiplicative factor $\Lambda_{i}$. At this point in the analysis, this term could reflect the level of technology used in the city, the average level of human capital of its work force, or city infrastructure, among other things. We pursue the second of these possible interpretations, allowing total factor productivity to evolve over time, in Section IV below.

We introduce the notion of urban land scarcity in a very simple way. Total factor productivity diminishes with distance from the city center. Specifically, output a distance $d$ from the center, $Q_{d}$, is:

${ }^{16} \mathrm{As}$ long as capital is perfectly mobile across cities, its incorporation into the analys is is straightforward and inconsequential. 


$$
Q_{d}=\Lambda d^{-\epsilon}(2 \pi d) \beta_{L_{d}^{1-\beta}}^{-15-} \quad \beta, \epsilon \in(0,1)
$$

where $L_{d}$ is the labor input a distance $d$ from the center of the city and, of course, $2 \pi d$ is the land input. (Since our focus here is on a single city, we omit the city-subscript i.) Total factor productivity a distance d from the city center is $\Delta d^{-\epsilon}$, where parameter $\epsilon$ is the elasticity of total factor productivity with respect to distance from the city center. We restrict the land share $\beta$ to exceed $\epsilon / 2$. Otherwise one city vould absorb the entire population, as indicated by equation (6) below.

Factors earn their (private) marginal products, so that payments to land and labor exhaust output. Worker mobility within the city establishes a common city vage $W$. For the private marginal product of labor to be equal across the city the amount of labor vorking a distance $d$ from the center must be :

$$
\mathrm{L}_{\mathrm{d}}=2 \pi\left\{\Lambda \mathrm{d}^{(\beta-\epsilon)}[(1-\beta) / \mathrm{H}]\right\}^{1 / \beta}
$$

The corresponding land rent is:

$$
\mathrm{R}_{\mathrm{d}}=\beta\left\{\operatorname{Ad}^{-\epsilon}[(1-\beta) / W]^{1-\beta}\right\}^{1 / \beta}
$$

which falls as distance from the center increases.

Land has an alternative nonurban use that yields $\mathbb{R}_{a}$. The distance from the center at which $R_{d}$ has fallen to $R_{a}$ establishes the city limits $D$. This condition relates the radius of the city $D$ to the vage $W$ and to the average level of productivity $A$. Solving for $W$ : 


$$
V=(1-\beta)\left[A D^{-\epsilon}\left(\beta / R_{a}\right)^{\beta}\right]^{1 /(1-\beta)} .
$$

Hence a city's vage increases with its total factor productivity $A$, but falls with its area $D$ (or equivalently, as we show next, with its labor force $L$ ). Substituting (4) into (3) and integrating across all urban locations from the city center to the city limits gives an expression for the urban labor force $L$ in terms of city radius $D$ and total factor productivity $A$ :

$$
\mathrm{L}=\frac{2 \pi \beta}{2 \beta-\epsilon}\left[\mathrm{R}_{\mathrm{a}} \mathrm{D}^{\Gamma} /(\beta \mathrm{A})\right]^{1 /(1-\beta)}
$$

where $\Gamma \equiv 2(1-\beta)+\epsilon$. This expression implies that greater total factor productivity reduces the labor force, given city area. The reason is that a smaller labor input is needed to offset the effect of greater total factor productivity on rent.

Finally, (4) and (5) together provide an expression for the wage in terms of productivity and the effective labor force, with the area determined endogenously:

$$
V=(1-\beta)\left\{[2 \pi \beta /(2 \beta-\epsilon)]^{\epsilon}\left(\beta / R_{\mathrm{a}}\right)^{2 \beta-\epsilon} \mathrm{A}^{2} \mathrm{~L}^{-\epsilon}\right\}^{1 / \Gamma} .
$$

As one would expect, given its labor force, the wage in a city is higher the higher total factor productivity and, given total factor productivity, the smaller the labor force.

Expression (6) relates the vage per unit of effective labor in a city to the city's effective labor force and its total factor productivity. To construct the equilibrium configuration of cities we need a theory of intercity migration. Simply postulating that labor is perfectly mobile across 
cities, and that workers seek out the highest wage, would imply that cities with higher total factor productivity will have larger effective labor forces. In the next section we develop a theory of total factor productivity grouth based on the accumulation of human capital. The level of total factor productivity is consequently endogenous. The implications for migration and city size are not as straightforward. Nevertheless, the association between higher total factor productivity and greater population remains. We defer the determination of relative city size and migration to Section $V$.

\section{1 DYNAYIC YODEL OF LEARNING AND URBAN GROYTH}

We now develop a theory of total factor productivity growth generated by investment in human capital. The accumulation of human capital in each city derives from the dynamic optimization problem facing the representative resident of that city. He characterize the solution to that problem and provide conditions under which the decisions of the representative residents of different cities lead to steady-state growth in a system of $\mathbb{K}$ cities interconnected by knowledge flows.

To simplify things we assume that the nonurban rent $R_{a}$ is common to all cities and remains constant over time. Denoting the physical labor force in city $i$ as $N_{i}$, the average level of human capital in that city as $H_{i}$, and the average time vorked per vorker as $e_{i}$, the effective labor supply in city $i$ is $L_{i}=e_{i} N_{i} H_{i}$. We follow Lucas (1988) in assuming that the average level of human capital in the community influences total factor productivity there, although we treat the community as the city rather than the country. ${ }^{17}$ Hence

\footnotetext{
${ }^{17}$ Again, allowing productivity to depend on the national average level of human capital as vell as on the average city level vould not affect our basic results. What is key is that the city average matter.
} 
$A_{i}=H_{i}^{\gamma}$, where $\gamma$ is a parameter relating city $i$ 's average level of human capital to its total factor productivity.

Guman Capital dccumulation and Growth

Incorporating the expression for effective labor into expressions (5) and (6), and differentiating with respect to time gives an expression (with e held constant) for the growth in the wage per unit of effective labor:

$$
g_{w}=\frac{(2 \gamma-\epsilon) g_{H}-\epsilon g_{N}}{\Gamma},
$$

so that growth in the wage per physical worker, which in steady state is the growth rate in per capita output and consumption, is:

$$
g_{c}=g_{w}+g_{H}=\frac{2(1-\beta+\gamma) g_{H}-\epsilon g_{N}}{\Gamma} \text {. }
$$

While more rapid accumulation of human capital can lower growth in the wage per unit of effective labor, it always means higher consumption growth. Whether per capita consumption grows or falls over time depends upon whether the effect of human capital accumulation overcomes the congestion effects of population growth.

We now consider what determines the rate of human capital accumulation.

\section{Learning}

As in Lucas (1988), workers must take time off from work to acquire human 
capital. Workers have a time endowment of 1 out of which to choose time at work e. The rest of the time they learn.

Also as in Lucas, productivity of time spent learning increases with what has been learned already, but Lucas assumes that the individual's own level of human capital is what matters. Instead, we posit that learning productivity depends upon a linear combination of the average levels of human capital in each city. ${ }^{18}$ Yoreover, we assume that cities differ intrinsically in the environment that they provide for acquiring human capital. Our specific assumption is that the increase in a vorker $k$ 's level of human capital $h_{k i t}$ in city is :

$$
\dot{\mathrm{h}}_{\mathrm{kit}}=\tilde{\mathrm{H}}_{\mathrm{it}}\left(1-\mathrm{e}_{\mathrm{kit}}\right)
$$

where $\tilde{H}_{i t}$ is the knowledge base that an individual in city $i$ draws upon in acquiring human capital. Here $e_{k i t}$ is worker $k$ 's own time spent working (so that $1-e_{k i t}$ is worker $k$ 's time learning).

We make the specific assumption that:

$$
\overline{\mathrm{H}}_{\mathrm{it}}=\sum_{\mathrm{j}} \delta_{i j} \mathrm{H}_{\mathrm{jt}}
$$

where $\delta_{i j}$ reflects the contribution of $-c i t y j$ 's average level of human capital to learning in city $i$. If city $i$ has larger values of $\delta_{i j}$ than some other city then it is a more productive place to learn, while if city $j$ has larger values of $\delta_{i j}$ than some other city then its human capital contributes more to learning. To the extent that the matrix of $\delta$ 's is heavily diagonal dominant

18Allowing productivity of learning time to depend on the worker's own level of human capital as well would not materially affect our analysis. 
then growth is largely generated by factors specific to the city in question. Less diagonal dominance implies more pooling of knowledge across cities.

\section{Single-City Dynamics}

We assume that cities are connected by a common capital market, so that individuals in any city can borrow and lend at a given interest rate $r$, which we treat as constant. Since ve ignore leisure and risk, optimal learning decisions maximize the discounted present value of wage income. Hence we need only concern ourselves with workers' decisions about allocating time between learning and working, which are independent of their decisions about consuming and saving.

At each period $t$, then, individual $k$ in city $i$ with human capital $h_{k i t}$ chooses $e_{k i t}$ to maximize:

$$
\int_{0}^{\infty} e^{-r \tau}{ }_{i} \tau_{k i \tau} e_{k i \tau} d \tau
$$

subject to the equation of motion (9).

Solving the problem for individual $k$ in city $i$ implies that, at an interior solution (in which an individual both learns and works):

$$
r+g_{H_{i}}-g_{w_{i}}=\tilde{H}_{i t} / h_{k i t} \text {. }
$$

where $g_{v_{i}}$ is the growth of the wage in city $i$, and $\tilde{g}_{H_{i}}$ is the grouth rate of city i's knowledge base.

Condition (10) is independent of $e_{k i t}$ itself. The reason is that the 
returns to working and learning are each linear in time spent in that activity. Hence, at an interior solution, an individual is indifferent between the two undertakings. If the individual is both learning and working, then the two activities must yield that person the same marginal, and hence average, return.

Yoreover, if the right-hand side of expression (10) exceeds the left then the (average and marginal) returns to learning exceed the returns to working so that the individual only learns, while if the left-hand side exceeds the right the individual only works.

Issimilation

For the representative resident of a city (for whom $h_{k i t}=H_{i t}$ ) to be willing both to work and to learn, then, requires that:

$$
r+\tilde{g}_{H_{i}}-g_{u_{i}}=\tilde{H}_{i} / H_{i}
$$

A particular implication of expressions (10) and (10'), which is important to the migration decision that we analyze below and in the appendix, is that an immigrant arriving in a city in which the representative resident is both working and learning will eventually become assimilated. An immigrant arriving with a level of human capital below the city average will find the reward to learning strictly greater than the reward to working, so will only learn. The immigrant's human capital will consequently grow faster than the city average until it catches up. Conversely, an immigrant arriving with a level of human capital above the city average will find the reward to working strictly greater than the reward to learning, so will only work. Since the 
immigrant's human capital level stops growing, the city average will eventually catch up with that of the immigrant. Either way, the immigrant eventually becomes just like the representative resident of the city of destination.

Steady-State growth

In steady state: (i) each city's average level of human capital and population (and hence, by equations (4) and (5), each city's area and wage) grow at the same rate; (ii) each individual's human capital corresponds to the city-wide average; ( $i i i)$ individuals have no reason to migrate between cities. Criteria (i) and (ii) determine the steady-state growth rate of human capital, while criteria (iii) establishes relative steady-state populations. Ve first establish conditions under which a unique steady-state growth rate exists, and then turn to the determination of relative city size in Section $V$.

We have already noted that, within a city, the average level of human capital vill move toward the average for that city. Criterion (i) implies that expression (10') hold for each city, with the same left-hand side applying to each city. Hence the right-hand side must be equal across cities as well.

Individuals' savings and consumption decisions determine the nationwide interest rate $r$. With Bernoulli preférences the steady-state interest rate equals the pure rate of time preference plus the growth in per capita consumption, $g_{c}$, equal to the growth in human capital plus the growth in the wage per unit of effective labor. Hence:

$$
r=\rho+g_{c}=\rho+g_{H}+g_{W}
$$


Substituting (11) into (10') implies that, in steady state, for each city i :

$$
\rho+2 g_{H}=\tilde{H}_{i} / H_{i}
$$

Since the left-hand side of expression (12) is independent of $i$, we can write (12) for all cities $i=1, \ldots X$ in matrix form as:

$$
\lambda H=\Delta H
$$

where $\lambda=\rho+2 \mathrm{~g}_{\mathrm{H}}$, $\mathrm{H}$ is the vector of city-level human capital $\left\{\mathrm{H}_{1}, \ldots, \mathrm{H}_{\mathrm{K}}\right\}$, and

$$
\Delta=\left[\begin{array}{llll}
\delta_{11} & \delta_{12} & \ldots & \delta_{1 \mathrm{~K}} \\
\delta_{21} & \delta_{22} & & \delta_{2 \mathrm{~K}} \\
\ddot{\delta}_{\mathrm{K} 1} & & \ldots & \delta_{\mathrm{KK}}
\end{array}\right]
$$

the matrix of city interaction effects.

Steady-state growth requires that this system have an eigenvalue that exceeds $\rho$ whose corresponding eigenvector is nonnegative. Since $\Delta$ is nonnegative, Frobenius' theorem ensures that if $\Delta$ is also indecomposable then it has a real eigenvalue $\lambda^{F}$ (the Frobenius root) where:

(i) $\lambda^{F}$ is real and strictly positive;

(ii) associated with $\lambda^{F}$ is an eigenvector $H^{F}>0$ which is unique up to a scalar multiple;

(iii) $\lambda^{F}$ is the only eigenvalue of $\Delta$ that has an associated eigenvector that is nonnegative; 
(iv) $\lambda^{F}$ is the largest eigenvalue in absolute value;

(v) $\lambda^{F}$ is increasing in each element of $\Delta .19$

These properties ensure that if $\Delta$ is indecomposable and its elements are sufficiently large then there exists a unique steady state growth rate of human capital $g_{H}=\left(\lambda^{F}-\rho\right) / 2$. The corresponding eigenvector ${ }^{F}$ gives the relative steady-state levels of human capital. More knowledge spillovers imply higher growth. If, however, the elements of $\delta$ are so small that $\lambda^{F}<\rho$ then no learning or growth occurs in steady state.

The matrix $\Delta$ is indecomposable if there is no ordering of its elements that allows it to be partitioned as:

$$
\Delta=\left[\begin{array}{ll}
\Delta_{11} & \Delta_{12} \\
0 & \Delta_{22}
\end{array}\right] .
$$

If $\Delta$ is decomposable then the cities corresponding to the elements of $\Delta_{22}$, what we call the isolated set of cities, do not receive spillovers from any city corresponding to the elements of $\Delta_{11}$. Even if $\Delta$ is decomposable, however, it still has a Frobenius root $\lambda^{F}$ if $\Delta_{12}$ has at least one strictly positive element (so that the set of cities corresponding to the elements of $\Delta_{11}$ are nonisolated) and $\Delta_{11}$ and $\Delta_{22}$ have Frobenius roots $\lambda_{1}^{F}$ and $\lambda_{2}^{F}$ such that $\lambda_{2}^{F} \geq \lambda_{1}^{F}$. In this case $\lambda^{F}=\lambda_{2}^{F}$ : The levels of human capital in the entire set of cities grow at the same rate as in the isolated set of cities left on their own. In this particular case the isolated cities are "leaders" in that these cities drive the growth of the others. If, hovever, $\lambda_{2}^{F}\left\langle\lambda_{1}^{F}\right.$ and $\lambda_{1}^{F}>\rho$ then the isolated cities eventually grow more slowly than the nonisolated set, and

\footnotetext{
19See McKenzie (1960, Lemma 1) or Takayama (1974, Theorem 4.B.1).
} 
get left behind.

Note that $\lambda^{F}$ and $\mathbb{H}^{F}$ depend on only the parameters of the knowledge spillover matrix. An implication is that the relative levels of human capital depend on only these parameters as well, and that the growth rate of human capital depends on only these parameters and the discount factor $\rho$.

In the special case of two cities $(K=2)$ we get that:

$$
\begin{aligned}
& \lambda^{F}=\frac{\delta_{11}+\delta_{22}+\left[\left(\delta_{11}-\delta_{22}\right)^{2}+4 \delta_{12} \delta_{21}\right]^{1 / 2}}{2} \\
& \frac{\mathrm{H}_{1}^{\mathrm{F}}}{\mathrm{H}_{2}^{\mathrm{F}}}=\frac{\delta_{11}-\delta_{22}+\left[\left(\delta_{11}-\delta_{22}\right)^{2}+4 \delta_{12} \delta_{21}\right]^{1 / 2}}{2 \delta_{21}} .
\end{aligned}
$$

Other things equal, the city in which the contribution of existing knowledge to learning is greater has a relatively higher level of human capital.

So far we have established conditions for the parallel growth of human capital across cities. We do not, hovever, have observations on the human capital levels of the cities but on their populations. Our theory implies that if the population of each city is also growing at a common rate, then so are vages and consumption, with parameters of technology linking the growth of human capital and population, on one hand, to the growth of wages and consumption, on the other.

Individual migration decisions link the distribution and growth of human capital to the size distribution of cities. We now turn to the migration decision of the representative resident of each city, and consider conditions under which the parallel growth of human capital levels across cities implies 
parallel growth of populations.

\section{v. MUGRTION AND CITY SIZE}

We now turn to the third criterion for a steady state, that the representative resident of each city have no incentive to migrate elsewhere. This criterion determines relative city populations in steady state.

The city-specificity of human capital

An issue is the degree to which the human capital acquired by someone in one city contributes to that individual's productivity elsewhere. At one extreme, human capital might be perfectly general, and augment labor productivity by the same amount anywhere. At the other extreme, human capital might be totally city-specific, not enhancing productivity anywhere except where it was acquired.

We introduce the parameter $p$ to deflate human capital acquired elsewhere than in the city where it is used. A migrant from city $i$ to $j$ with an amount of human capital h acquired in the city of origin will arrive in city $j$ with an amount of human capital $p$. Hence a value of $p=1$ implies that human capital is fully general, while $\varphi=0$ implies that it is completely city-specific.

In analyzing a decision to migrate we need to distinguish between a move to a city where the migrant's human capital, upon arrival, will be lower than the average of the city of destination and a move to a city where the migrant will find his own level of human capital above average. We undertake this 
analysis for an individual contemplating a move in an economy that is in steady state.

\section{Joving up}

Consider first an individual's decision about whether or not to migrate from city $i-1$ to city $i$, where $H_{i}>\varphi H_{i-1}$. The immigrant vould arrive in city $i$ with a lower level of human capital than the destination average. Ve shoved in part IV that, upon arrival, the immigrant vould devote all available time to learning until becoming assimilated with the representative resident in the destination city. Vage income during this training period would be zero, but once it was over the immigrant would resume working the steady-state amount.

Ve denote the steady-state present income of an individual with human capital $h$ remaining thereafter in a city with an average level of human capital $H$ as $V(h, H)$. We derive this function for the cases $h=H, h<H$, and $h>H$ in the appendix.

Hence the value to the potential migrant of remaining at home is given by $V\left(H_{i-1}, H_{i-1}\right)$, as given in equation $(A 1)$ in the appendix, while the value of moving to city $\mathrm{i}$ and remaining there is $\mathrm{V}\left(\varphi \mathrm{H}_{i-1}, \mathrm{H}_{i}\right)$, with $\mathrm{V}$ taking the form given in expression (A2).

Hence there is an incentive to migrate from city $i-1$ to city $i$ if $V\left(\varphi H_{i-1}, H_{i}\right)>V\left(H_{i-1}, H_{i-1}\right)$. For the wage differential to remove this incentive, the radius of city $i$ must exceed that of $i-1$ by at least the ratio:

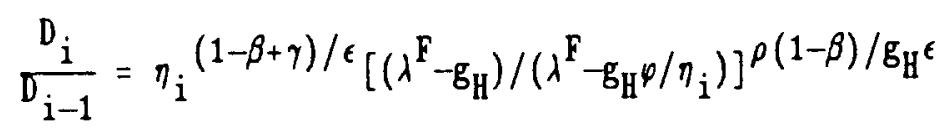

where $\eta_{i}=H_{i} / H_{i-1}$ is the ratio of human capital city at rank $i$ to that of 
city at rank $i-1$, and $g_{H}=\left(\lambda^{F}-\rho\right) / 2$, the steady-state growth rate of human capital.

The city with the higher steady-state level of human capital must have a larger area in order to deter migration from the lover human capital city. It must also have more effective labor, and a larger population, as can be seen by combining this expression with (5), to obtain:

$$
\frac{L_{i}}{L_{i-1}}=\eta_{i}(\Gamma+2 \gamma) / \epsilon\left[\left(\lambda^{F}-g_{H}\right) /\left(\lambda^{F}-g_{H} \varphi / \eta_{i}\right)\right]^{\rho \Gamma / g_{H} \epsilon} .
$$

and, since $L_{i}=H_{i} N_{i}$, where $N_{i}$ is the physical population of city $i$ :

$$
\frac{N_{i}}{N_{i-1}}=\eta_{i}^{2(1-\beta+\gamma) / \epsilon}\left[\left(\lambda^{F}-g_{H}\right) /\left(\lambda^{F}-g_{H^{\varphi}} \varphi / \eta_{i}\right)\right]^{\rho \Gamma / g_{H} \epsilon} .
$$

These expressions are lower bounds on how much the size of a city with higher human capital must exceed that of a city with lover human capital to remove migration incentives. If this bound is violated, vorkers in the lover human capital city have an incentive to migrate to the higher human capital city.

Note that this lower bound on the relative population of city $i$ to that of city i-1 depends on all the parameters of the model, which we assume are the same for all cities, and on the ratio of human capital of the two cities.

\section{Yoving Down}

Eliminating the corresponding incentive to move from a high to a low human capital city places an upper bound on how much the size of the high 
human capital city can exceed that of the low human capital city. To establish these bounds consider now an individual in city $i$ contemplating a move to city $\mathrm{i}-1$, where $\varphi \mathrm{H}_{i}>\mathrm{H}_{\mathrm{i}-1}$.

Since the immigrant arrives with a level of human capital that exceeds the average in the destination city, the immigrant's incentive is to vork full time, not learning at all, until the human capital level in the city has caught up to the immigrant's level. The potential migrant now compares the value of staying home, $\mathrm{V}\left(\mathrm{H}_{\mathbf{i}}, \mathrm{H}_{\mathrm{i}}\right)$ as given by $(\boldsymbol{\Lambda} 1)$, with that moving to city i-1. The value of making this move permanently is $\mathrm{V}\left(\varphi \mathrm{H}_{i}, \mathrm{H}_{i-1}\right)$, where the relevant expression for $V$ is given by (A3).

To remove the incentive to migrate from city $i$ to city $i-1$, the maximum amount by which city i's radius can exceed that of city i-1 is:

$$
\frac{D_{i}}{D_{i-1}}=\eta_{i}^{(1-\beta+\gamma) / \epsilon}\left[(1-\theta)\left(\varphi \eta_{i}\right)^{-\rho / g_{H}}+\theta \varphi \eta_{i}\right]^{(\beta-1) / \epsilon}
$$

where:

$$
\theta \equiv \frac{\rho}{\left(\rho+g_{\mathrm{H}}\right) \mathrm{e}^{\boldsymbol{*}}}
$$

and $\mathrm{e}^{*}=\left(\lambda^{\mathrm{F}}+\rho\right) / 2 \lambda^{\mathrm{F}}$ is the steady-state vork effort.

If city i-1 were any smaller relative to city $i$, it would attract immigration from the larger city. The maximum difference in human capital is:

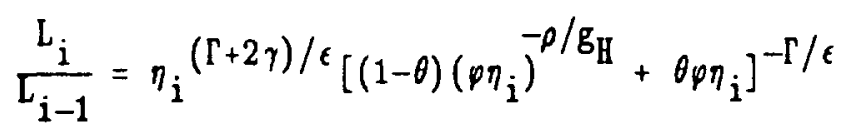

while the maximum population difference is: 


$$
\frac{N_{i}}{N_{i-1}}=\eta_{i}^{2(1-\beta+\gamma) / \epsilon}\left[(1-\theta)\left(\varphi \eta_{i}\right)^{-\rho / g_{H}}+\theta \varphi \eta_{i}\right]^{-\Gamma / \epsilon} .
$$

A steady state requires that the lower bound not exceed the upper bound. The interval of permissible city sizes falls as $\varphi$ rises. In our simulations the interval became negative with strictly positive discounting $(\rho>0)$ and values of $\varphi$ very close to one. The implication is that, with discounting, a steady-state outcome with multiple cities requires some element of city specificity of human capital (or some other form of moving cost). ${ }^{20}$ With discounting but no impediment to migration, residents have an incentive to switch cities occasionally, moving to lower human capital cities when their human capital is high and working there full time, but later moving to higher human capital city to replenish their human capital.

The rest of our discussion here posits that values of $\varphi$ and $\rho$ guarantee a steady state with no equilibrium migration. We discuss two particular cases in which a steady state is guaranteed:

$$
\text { fully city-specific human capital }
$$

Say that $\varphi=0$, so that knowledge acquired in one city has no value elsewhere. In this case there is no possibility of "moving down," since one arrives anywhere new with no human capital that is appropriate for the city of destination. Yoreover, there is no reason to migrate temporarily to a high human capital city for the purpose of learning since any knowledge acquired

200 ur calculations compare the value of staying in the city of origin with that of a permanent move to another city. Hence the bounds that ve derive are necessary but not sufficient for a steady state: $\boldsymbol{A}$ steady state could be upset by the temptation to undertake even a temporary move to another city. A $\emptyset$ sufficiently close to zero (or some other sufficiently high transport cost) can render even temporary moves unattractive, however, as we discuss below. 
there would be useless anywhere else. Expressions (14), (15), and (16), evaluated at $\varphi=0$, thus provide lover bounds on the extent to which the area, effective labor force, and population of city $i$ can exceed those of city i-1. The upper bounds are given by the condition that $\mathrm{V}\left(\mathrm{O}, \mathrm{H}_{\mathrm{i}-1}\right)<\mathrm{V}\left(\mathrm{H}_{\mathrm{i}}, \mathrm{H}_{\mathrm{i}}\right)$, i.e., that it is not worthwhile moving to the lover human capital city to start over there. This upper bound necessarily exceeds the lover bound established by the condition that $\mathrm{V}\left(\mathrm{H}_{\mathrm{i}-1}, \mathrm{H}_{\mathrm{i}-1}\right)>\mathrm{V}\left(\mathrm{O}, \mathrm{H}_{\mathrm{i}}\right)$.

\section{zero discounting}

In the special case in which there is no pure time discounting $(\rho=0)$ only steady state human capital levels matter in determining comparisons across cities. The lower and upper bounds on city radius, effective labor, and population differences converge to:

$$
\begin{aligned}
& \frac{D_{i}}{D_{i-1}}=\eta_{i}(1-\beta+\gamma) / \epsilon \\
& \frac{L_{i}}{L_{i-1}}=\eta_{i}(\Gamma+2 \gamma) / \epsilon
\end{aligned}
$$

and:

$$
\frac{N_{i}}{N_{i-1}}=\eta_{i}^{2(1-\beta+\gamma) / \epsilon}
$$

respectively.

In this special case, then, relative steady state city size leaves the residents of each city indifferent between staying put or moving to any other, 
larger or smaller, city. The city-specificity of human capital makes no difference since the destination city's level of human capital is always acquired in finite time. The larger size (or, equivalently, higher land rents) of cities where learning is more productive make them equally attractive as cities where learning is less productive.

Equation (16") thus provides a simple relation between average levels of human capital and the relative population of the cities. This relationship depends on all the parameters of the model (which we treat as common to all cities) and relative total factor productivities (which in our analysis are determined by relative average levels of human capital) among cities. More generally, with potential migration, relative population levels provide a fairly tight, but possibly not exact, measure of the relative levels of total factor productivity in different locations.

The model thus provides an explanation for the observed stability of the relative populations of cities. The spillover of knowledge between and within cities determines the common rate of growth of total factor productivity of all cities, and their ranking. The migration decision then implies a restriction on the distribution of population among cities. Without discounting, the relative human capital level of a city uniquely determines its relative size. With discounting the growth rate of human capital, which is equal across cities, has an effect on the bounds of the city size as vell. Simulation results indicate that, with plausible parameter values, very small differences in steady-state human capital levels (around 5 per cent) can imply large differences in city populations and areas.

Higher costs of congestion are captured by higher values of $\epsilon$. Raising $\epsilon$ does not change the distribution of human capital (agglomeration) among cities, but from (16") we can see that the distribution of city sizes become 
flatter, so that the ratio $N_{i} / N_{i-1}$ is smaller. Hence the shape of the Lorenz curves is affected by both the process of human capital accumulation and the parameters of the production function and preferences. However, if these parameters are stable, the dynamic structure of human capital accumulation alone can explain the stability of the Lorenz curve, and our observation that there are no "nev" cities and that no city "dies."

\section{CONCLUSION}

The French and Japanese experiences provide striking evidence that, while the process of development is associated with a significant increase in urban population, it has had little effect on the distribution of population among different urban areas. This finding suggests that the forces driving the process of industrialization are present in individual cities in proportion to their initial populations.

In economies with labor mobility, per capita output or wages are a poor indicator of total factor productivity across regions. 21 We have developed an equilibrium model in which relative populations reflect total factor productivity differentials across cities. Hence, the observed parallel growth of urban populations in France and in Japan can be interpreted as evidence for parallel growth in total factor productivity across cities. The model also suggests how cities can serve as a fundamental force in the process of industrialization.

The structural link between the dynamic process of human capital growth

\footnotetext{
2LLand rents would provide a much better measure. Onfortunately data on land rents are rarely available comprehensively. An exception is Japanese data on land values by prefecture. Dekle and Eaton (1993) explore their implications for measuring agglomeration effects in manufacturing and in financial services.
} 
and the growth and distribution of population among cities is the central aspect of the theory. This link implies that we can use the data on the populations of cities to measure the pattern of growth of total factor productivity. In this paper we use this implication to interpret the stability of the Lorenz curves.

Our theory, taken literally, would also imply that the matrix describing the transition of cities across relative sizes ( $\mathbb{M}$, in equation (1)) is diagonal. we found in section II, hovever, that the matrix $y$ includes off diagonal terms. We interpret these off diagonal terms using a stochastic version of the model in a sequel to this paper.

Our theory is compatible with many possible relationships among cities in a growing country. One possibility is that the matrix $\Delta$ of knowledge spillovers is nearly diagonal, which would suggest that cities are largely "self reliant" in terms of their growth. In this case the process of economic development is best thought of in terms of the city. Another possibility is that off-diagonal elements are large, in which case the growth of individual cities is highly interconnected. In this case the nation or some broader unit might provide the more appropriate unit of analysis. In our sequel paper we use the stochastic formulation of our analysis to estimate knowledge spillovers themselves.

Our analysis also has implications for the relationship between migration and development. It suggests, for example, how changes in the way knowledge flows across locations, as well as changes in land shares and urban transportation technology and infrastructure, would affect migration patterns and relative city size. Extensions of the analysis could also have implications for the relationship between migration and human capital accumulation. The analysis above suggests that migrants moving tovard more 
populated cities would tend to be less educated than average upon arrival, but would acquire human capital more quickly once they arrive. Migrants to less populated regions would have the opposite characteristics. 
REFERENCES

Arnott, R. (1979), "Optimum City Size in a Spatial Economy," Journal of Orban Bconomics, 6: 65-89.

Barro, R.J. (1991), "Economic Growth in a Cross Section of Countries," Quarterly Journal of Bconomics, 106: 407-444.

Barro, R.J. and X. Sala-I-Yartin (1992), "Convergence," Journal of Polical Bconomy, 100: 223-251.

Beckmann, M.J. (1958), "City Hierarchies and Distribution of City Size," Bconomic Development and Cultural Change, 6: 243-248.

Chenery, H.B. and Y. Syrquin (1975), Patterns of Development: 1950-1970 (London: Oxford University Press).

Dekle, R. and J. Eaton (1993), "Agglomeration and the Price of Land: Theory and Evidence from the Prefectures." manuscript, Boston University.

Glaiser, E.L., H.D. Kallal, J.A. Scheinkman, and A. Shleifer (1992), Growth in Cities," Journal of Political Bconomy, 100: 1126-1152.

Grossman G.M. and E. Helpman (1991), Innovation and Growth in the Vorld Bconomy (Cambridge, MA: MIT Press).

Henderson, J.V. (1987), "General Equilibrium Modeling of Systems of Cities," Bandbook of Regional and Orban Bconomics, Volume II, Edited by E.S. Mills (Amsterdam: Elsevier Science Publishers).

Henderson, J.V. (1988), Orban Development: Theory, Fact, and Illusion (New York: Oxford University Press).

Helpman, E. and D. Pines (1980), OPtimal Public Investment and Dispersion Policy in a System of Open Cities," Imerican Bconomic Peview, 70: 507-514.

Inada, K. (1969), "Endogenous Technical Progress and Steady-State Growth, Peview of Bconomic Studies, 36: 99-108.

INSEE, Innuaire Statistique, various issues.

Jacobs, J. (1969), The Bconomy of Cities (New York: Vintage Books).

Jacobs, J. (1984), Cities and the Vealth of Nations (New York: Vintage Books).

Ianketsu Showa-kokusei Soran.

Kuznets, S. (1966), Modern Bconomic Growth (New Haven: Yale University Press). 
Lucas, R.E. (1988), "0n the Mechanics of Economic Development," Journal of Nonetary Economics, 22: 3-42.

Lucas, R.E. (1993), "Making a Kiracle," Econometrica, 61.

Mills E.S. (1967), "An Aggregative Nodel of Resource Allocation in a Metropolitan Area," Imerican Bconomic Peview, 57: 197-210.

McKenzie, L. (1960), "Katrices vith Dominant Diagonals and Economic Theory," Yothematical Vethods in the Social Sciences, 1959, edited by K.J. Arrow, S. Rarlin, and P. Suppes (Stanford University Press).

Miyao, T. (1987), "Dynamic Urban Models." Handbook of Regional and Orban Economics, Volume II, edited by E.S. Yills (Amsterdam: Elsevier Science Publishers).

Quah, D. (1993), "Empirical Cross-Section Dynamics in Economic Growth," European Economic Review, 37: 426-434.

Rauch, J. (1991), "Productivity Gains from Geographic Concentration of Human Capital: Evidence from the Cities," manuscript, University of California, San Diego.

Rodwin, L. (1970), Nations and Cities (Boston: Houghton-Mifflin).

Romer, P. (1986), "Increasing Returns and Long-Run Growth," Journal of Political Economy, 94: 1002-1037.

Solow, R.M. (1956), "A Contribution to the Theory of Economic Growth," Quarterly Journal of Economics, 70: 65-94.

Summers, R. and A. Heston (1991), "The Penn Vorld Table (Mark V): An Expanded Set of International Comparisons," Quarterly Journal of Economics, 106: 327-368.

Takayama, A. (1974), Nathematical Bconomics (Hinsdale, IL: Dryden).

Uzawa, H. (1965), "Optimum Technical Change in an Aggregative Model of Economic Growth," Internotional Bconomic Review, 6: 18-31.

Young, A. (1991), "Learning by Doing and the Dynamic Effects of International Trade," Puarterly Journal of Economics, 106: 369-406. 


\section{APPENDIX A: Migration and City Size}

Here ve derive the total discounted wage income, at some time 0 , of an individual with human capital $h_{0}$ remaining thereafter in city $i$. City $i$ has an average level of human capital $\mathrm{H}_{i, 0}$, which we assume is growing at the steady-state rate $g_{H}$. Ve denote the discounted wage earnings of this individual as $\mathrm{V}\left(\mathrm{h}_{0}, \mathrm{H}_{\mathrm{i}, 0}\right)$. In deriving this amount we need to distinguish three cases:

1. The representative resident:

The discounted present vage income of the representative resident, for whom $h_{0}=H_{i, 0}$, is simply:

$$
V\left(H_{i, 0}, H_{i, 0}\right)=e^{*} \frac{{ }^{w}, 0^{H}}{r-g_{w}-g_{H}}=e^{*} \frac{{ }_{i, 0}{ }^{H} i, 0}{\rho}
$$

where $e^{*}=\left(\lambda^{F}+\rho\right) / 2 \lambda$, the steady-state amount of time spent working.

2. The below-average resident:

Consider now a resident whose human capital is initially below the city average, so that $h_{0}<H_{i, 0}$. Expression (10) implies that this resident will choose $e=0$ as long as $h_{t}<H_{i, t}$.

How long does it take to acquire the city's average level of human capital? Define the ratio of the city-average level of human capital to that of the below-average resident at time $t$ as $x_{t}=H_{i, t} / h_{t}$. Since $\dot{h}_{t} / h_{t}=\lambda x_{t}$ : 


$$
\frac{\dot{x}_{t}}{x_{t}}=g_{H}-\lambda^{F} x_{t}
$$

a differential equation in $x_{t}$ solved by:

$$
x_{t}=\frac{x_{0} \exp ^{\mathrm{g}_{\mathrm{H}} \mathrm{x}_{0}}}{\frac{\mathrm{g}_{\mathrm{H}}}{\mathrm{g}_{\mathrm{H}} \mathrm{t}^{\mathrm{F}}}+1-\frac{\lambda^{\mathrm{F}} \mathrm{x}_{0}}{\mathrm{~g}_{\mathrm{H}}}} .
$$

At $\mathrm{T}^{\mathrm{u}}, \mathrm{x}_{\mathrm{T}^{\mathrm{u}}}=1$, so that :

$$
\exp ^{g_{H} T^{u}}=\frac{\lambda^{F}-g_{H} / x_{0}}{\lambda^{F}-g_{H}}
$$

Hence, for $\mathrm{h}_{0} \leq \mathrm{H}_{\mathrm{i}, 0}$ :

$$
V\left(h_{0}, H_{i, 0}\right)=e^{*} \exp ^{-\rho T^{u}} \frac{w_{i, 0}{ }_{i, 0}}{\rho}=e^{*}\left[\frac{\lambda^{F}-g_{H} / x_{0}}{\lambda^{F}-g_{H}}\right]^{-\rho / g_{H}} \frac{w_{i, 0} H_{i, 0}}{\rho} .
$$

3. The above-average resident

Finally, expression (10) implies that a resident with human capital initially above the city average (for whom $h_{0}>H_{i, 0}$ ) will spend no time learning as long as $h_{t}$ remains above $H_{t, 0}$. Hence this individual's human capital does not grow at all while the city average grows at rate $g_{H}$, until the city average catches up.

Let $\mathrm{T}^{\mathrm{d}}$ denote how long it will take the average level of human capital in 
the city to reach that of the initially above-average resident. To calculate $T^{d}$, denote the ratio of the resident's human capital level to the city-average as $y_{t}=h_{t} / H_{i-1 t}$. As long as $y_{t}>1, \dot{h}_{t}=0$ while $\dot{H}_{i-1} / H_{i-1}=g_{H}$, so that, in this range $\frac{\dot{y}_{t}}{y_{t}}=-g_{H}$. Hence, while $y_{t}>1, y_{t}=y_{0} \exp ^{-g_{H} t}$. Since $y_{T^{d}}=1, T^{d}$ is determined by the condition that $y_{0} \exp ^{-g_{H} T^{d}}=1$, or that:

$$
\exp ^{g_{H} T^{d}}=y_{0}
$$

$$
\begin{aligned}
& \text { Hence, for } h_{0} \geq H_{i, 0}: \\
& \qquad \begin{aligned}
V\left(h_{0}, H_{i}, 0\right. & =\int_{0}^{T^{d}} w_{i, t} h_{0} \exp ^{-r t} d t+e^{*} \int_{T}^{\infty} w_{i, t} H_{i, t} \exp ^{-r t} d t \\
& =\left(1-y_{0}{ }^{\prime} / g_{H}\right) \frac{w_{i, 0} h_{0}}{r^{\prime}}+e^{*} y_{0}-\rho / g_{H} \frac{w_{i-10}{ }^{H} i-10}{\rho}
\end{aligned}
\end{aligned}
$$

where $r^{\prime}=\rho+g_{H}=r-g_{k}$. The first term is discounted vage income during the period when the resident's human capital exceeds the city average, when no effort is devoted to human capital formation. The second term reflects earnings once the city's average human capital level meets that of the above-average individual's, at which point the individual reduces his vork effort to $e^{*}$. 
Figure 1

\section{Lorenz Curves for French Cities}

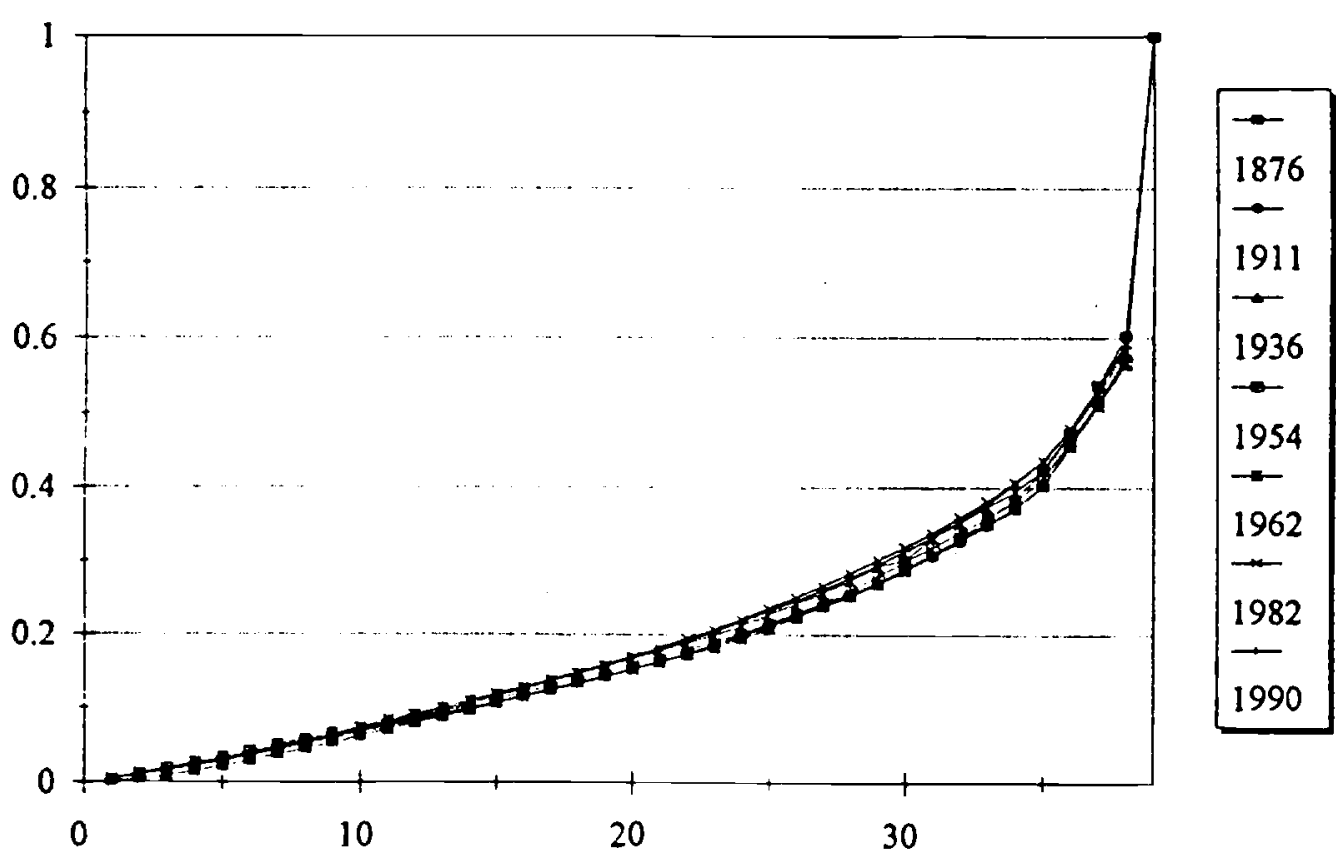




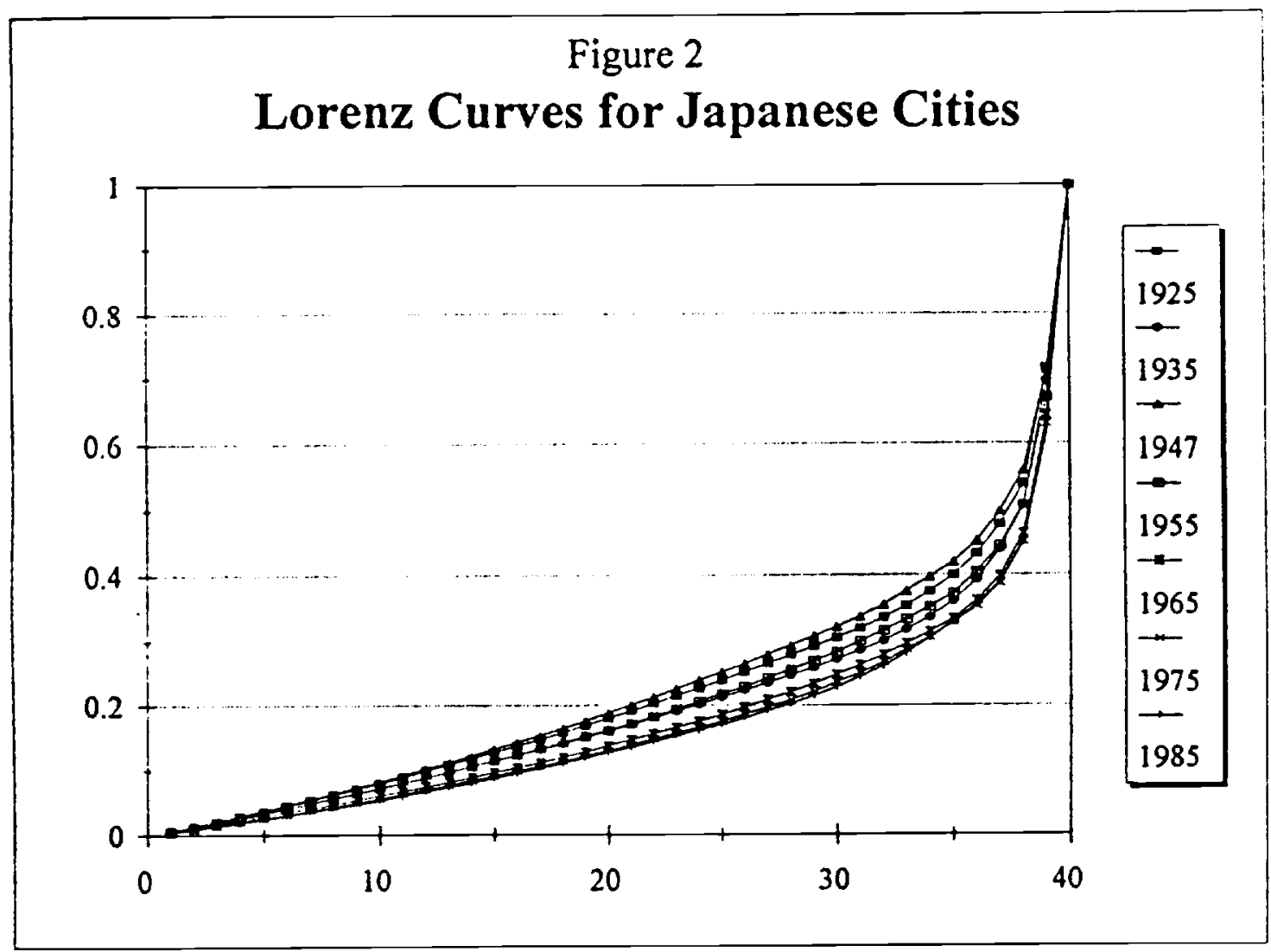


Figure 3 : French Cities

Growth Rates and 1876 Cities Size

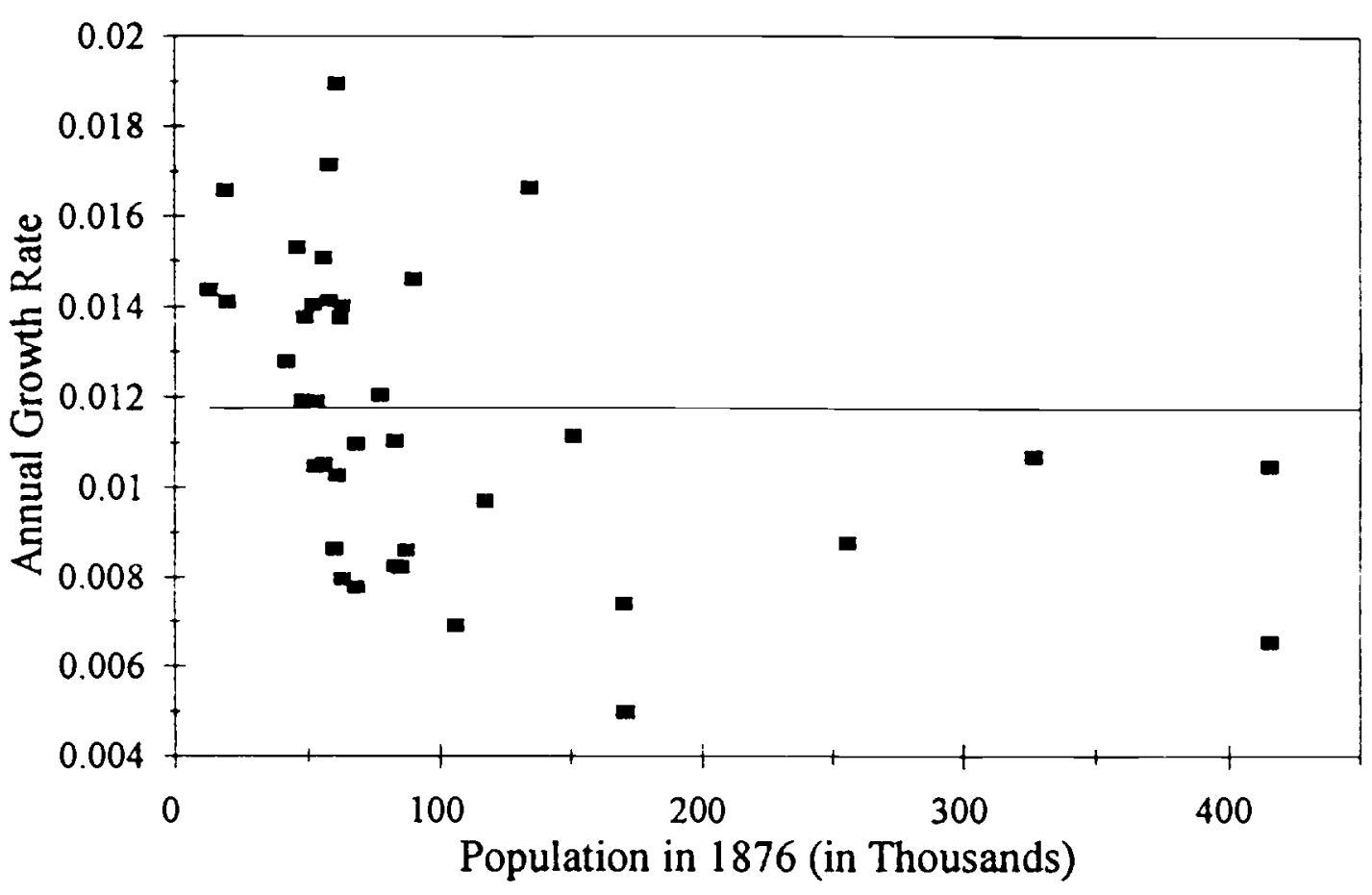

$\begin{array}{llll}\mathrm{R}-S q u a r e d & 0.0247 \quad \text { Coefficient } & -1.28 \mathrm{E}-06\end{array}$

No. of Observations $\quad 39 \quad$ Std. Error of Coef. $1.317 \mathrm{E}-06$ 
Figure 4 : Japanese Cities

Growth rates and 1925 cities size

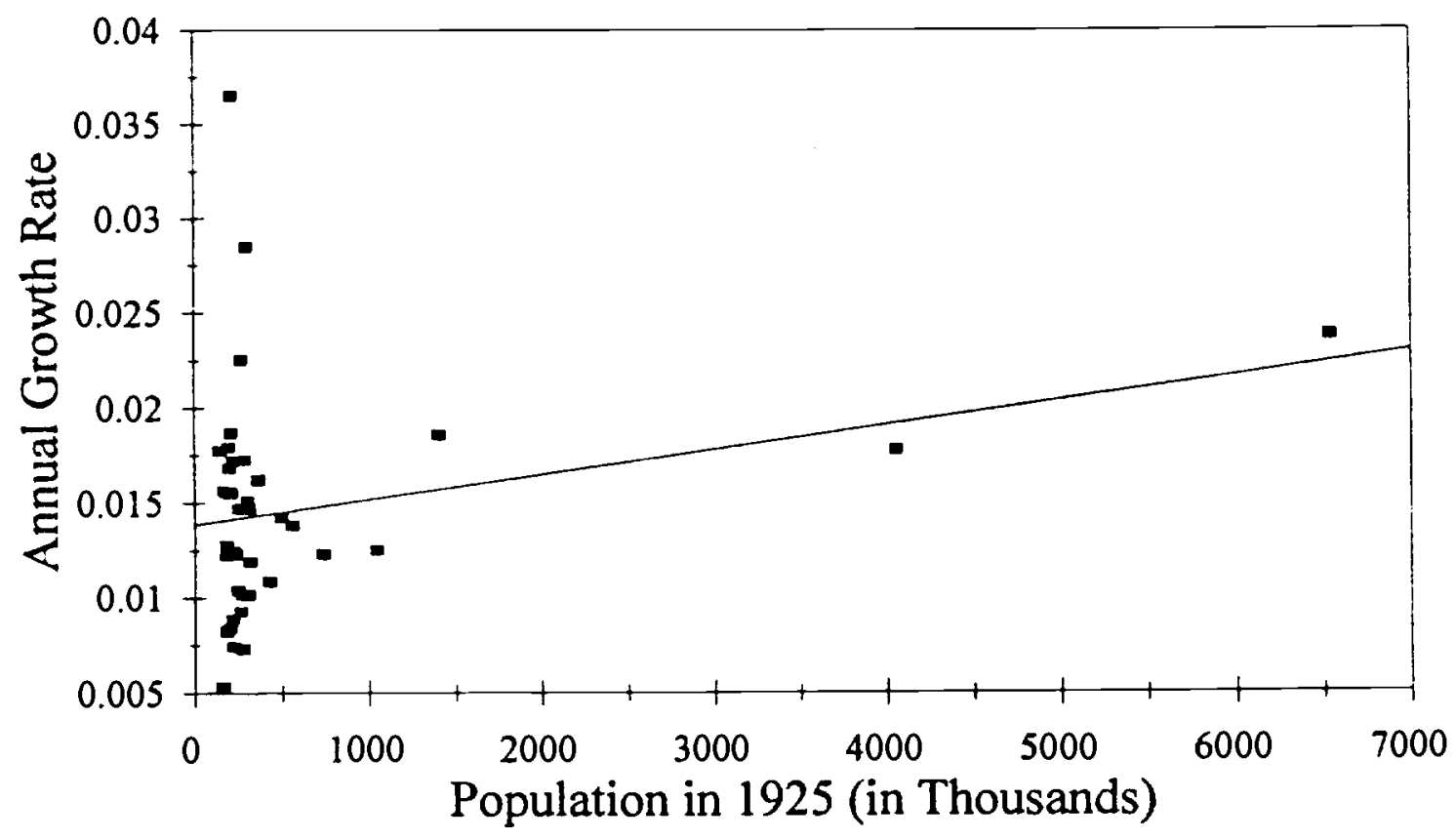

R-Squared

0.0708

Coefficient

1.3E-09

No. of Observations

40

Std. Error of Coef.

8E-10 
Table 1: Cross-Section Regressions for French Data

a. $\operatorname{Ln}($ Wage $)$ on $\operatorname{Ln}($ City's Population)

\begin{tabular}{|c|c|c|c|c|c|}
\hline Year & & & Year & & \\
\hline Constant & & 1.8644 & Constant & & 1.7787 \\
\hline Std Err of $Y$ Est & & 0.0219 & Std Err of Y Est & & 0.0362 \\
\hline R S Squared & & 0.3997 & R Squared & & 0.3789 \\
\hline No. of Observa & & 39 & No. of Observat & & 39 \\
\hline Degrees of Fre & & 37 & Degrees of Free & & 37 \\
\hline X Coefficient(s) & 0.0508 & & X Coefficient(s) & 0.0794 & \\
\hline Std Err of Coef. & 0.0102 & & Std Err of Coef. & 0.0167 & \\
\hline$T$ stat & 4.9638 & & T stat & 4.7506 & \\
\hline
\end{tabular}

b. Ln(Price) on Ln(City's Population)

\begin{tabular}{|lr|}
\hline Constant & 81.185 \\
Std Err of Y Est & 7.3627 \\
R Squared & 0.5867 \\
No. of Observations & 20 \\
Degrees of Freedom & 18 \\
& \\
X Coefficient(s) & 0.0044 \\
Std Err of Coef. & 0.0009 \\
\hline t stat & 5.0551 \\
\hline
\end{tabular}


Table 2: Frequency \& Relative Frequency for French Data

\begin{tabular}{|c|c|c|c|c|c|c|c|}
\hline & \multicolumn{6}{|c|}{ Cell's Upper Endpoint } \\
\hline & & 0.3 & 0.5 & 0.75 & 1 & 2 & 20 \\
\hline \multirow{2}{*}{1876} & Frequency & 7 & 18 & 5 & 2 & 4 & 3 \\
\hline & Probability & 0.179 & 0.462 & 0.128 & 0.051 & 0.103 & 0.077 \\
\hline \multirow[t]{2}{*}{1911} & Frequency & 11 & 12 & 7 & 4 & 1 & 4 \\
\hline & Probability & 0.282 & 0.308 & 0.179 & 0.103 & 0.026 & 0.103 \\
\hline \multirow{2}{*}{1936} & Frequency & 11 & 13 & 6 & 4 & 1 & 4 \\
\hline & Probability & 0.282 & 0.333 & 0.154 & 0.103 & 0.026 & 0.103 \\
\hline \multirow[t]{2}{*}{1954} & Frequency & & 15 & & 4 & & \\
\hline & Probability & 0.231 & 0.385 & 0.154 & 0.103 & 0.051 & 0.077 \\
\hline \multirow[t]{2}{*}{1962} & Frequency & & 15 & & & & \\
\hline & Probability & 0.205 & 0.385 & 0.154 & 0.128 & 0.051 & 0.077 \\
\hline \multirow[t]{2}{*}{1982} & Frequency & & 18 & & & & \\
\hline & Probability & 0.128 & 0.462 & 0.205 & 0.051 & 0.077 & 0.077 \\
\hline \multirow[t]{2}{*}{1990} & Frequency & & 17 & & & & \\
\hline & Probability & 0.154 & 0.436 & 0.205 & 0.051 & 0.077 & 0.077 \\
\hline
\end{tabular}


Table 3: Frequency \& Relative Frequency for Japanese Data

\begin{tabular}{|c|c|c|c|c|c|c|c|}
\hline & \multicolumn{6}{|c|}{ Cells Upper Endpoint } \\
\hline & & 0.3 & 0.5 & 0.75 & 1 & 2 & 20 \\
\hline 1925 & $\begin{array}{l}\text { Frequency } \\
\text { Prob. }\end{array}$ & $\begin{array}{r}2 \\
0.05\end{array}$ & $\begin{array}{r}23 \\
0.575\end{array}$ & $\begin{array}{r}8 \\
0.2\end{array}$ & $\begin{array}{r}2 \\
0.05\end{array}$ & $\begin{array}{r}2 \\
0.05\end{array}$ & $\begin{array}{r}3 \\
0.075\end{array}$ \\
\hline 1930 & $\begin{array}{l}\text { Frequency } \\
\text { Prob. }\end{array}$ & $\begin{array}{r}3 \\
0.075\end{array}$ & $\begin{array}{r}24 \\
0.6\end{array}$ & $\begin{array}{r}6 \\
0.15\end{array}$ & $\begin{array}{r}1 \\
0.025\end{array}$ & $\begin{array}{r}3 \\
0.075\end{array}$ & $\begin{array}{r}3 \\
0.075\end{array}$ \\
\hline 1935 & $\begin{array}{l}\text { Frequency } \\
\text { Prob. }\end{array}$ & $\begin{array}{r}6 \\
0.15\end{array}$ & $\begin{array}{r}23 \\
0.575\end{array}$ & $\begin{array}{r}4 \\
0.1\end{array}$ & $\begin{array}{r}2 \\
0.05\end{array}$ & $\begin{array}{r}2 \\
0.05\end{array}$ & $\begin{array}{r}3 \\
0.075\end{array}$ \\
\hline 1940 & $\begin{array}{l}\text { Frequency } \\
\text { Prob. }\end{array}$ & $\begin{array}{r}9 \\
0.225\end{array}$ & $\begin{array}{r}21 \\
0.525\end{array}$ & $\begin{array}{r}4 \\
0.1\end{array}$ & $\begin{array}{r}1 \\
0.025\end{array}$ & $\begin{array}{r}2 \\
0.05\end{array}$ & $\begin{array}{r}3 \\
0.075\end{array}$ \\
\hline 1947 & $\begin{array}{l}\text { Frequency } \\
\text { Prob. }\end{array}$ & $\begin{array}{r}2 \\
0.05\end{array}$ & $\begin{array}{r}20 \\
0.5\end{array}$ & $\begin{array}{r}10 \\
0.25\end{array}$ & $\begin{array}{r}3 \\
0.075\end{array}$ & $\begin{array}{r}2 \\
0.05\end{array}$ & $\begin{array}{r}3 \\
0.075\end{array}$ \\
\hline 1950 & $\begin{array}{l}\text { Frequency } \\
\text { Prob. }\end{array}$ & $\begin{array}{r}3 \\
0.075\end{array}$ & $\begin{array}{r}21 \\
0.525\end{array}$ & $\begin{array}{r}8 \\
0.2\end{array}$ & $\begin{array}{r}3 \\
0.075\end{array}$ & $\begin{array}{r}2 \\
0.05\end{array}$ & $\begin{array}{r}3 \\
0.075\end{array}$ \\
\hline 1955 & $\begin{array}{l}\text { Frequency } \\
\text { Prob. }\end{array}$ & $\begin{array}{r}6 \\
0.15\end{array}$ & $\begin{array}{r}21 \\
0.525\end{array}$ & $\begin{array}{r}6 \\
0.15\end{array}$ & $\begin{array}{r}2 \\
0.05\end{array}$ & $\begin{array}{r}2 \\
0.05\end{array}$ & $\begin{array}{r}3 \\
0.075\end{array}$ \\
\hline 1960 & $\begin{array}{l}\text { Frequency } \\
\text { Prob. }\end{array}$ & $\begin{array}{r}11 \\
0.275\end{array}$ & $\begin{array}{r}17 \\
0.425\end{array}$ & $\begin{array}{r}6 \\
0.15\end{array}$ & $\begin{array}{r}1 \\
0.025\end{array}$ & $\begin{array}{r}2 \\
0.05\end{array}$ & $\begin{array}{r}3 \\
0.075\end{array}$ \\
\hline 1965 & $\begin{array}{l}\text { Frequency } \\
\text { Prob. }\end{array}$ & $\begin{array}{r}15 \\
0.375\end{array}$ & $\begin{array}{r}13 \\
0.325\end{array}$ & $\begin{array}{r}6 \\
0.15\end{array}$ & $\begin{array}{r}1 \\
0.025\end{array}$ & $\begin{array}{r}2 \\
0.05\end{array}$ & $\begin{array}{r}3 \\
0.075\end{array}$ \\
\hline 1970 & $\begin{array}{l}\text { Frequency } \\
\text { Prob. }\end{array}$ & $\begin{array}{r}17 \\
0.425\end{array}$ & $\begin{array}{r}11 \\
0.275\end{array}$ & $\begin{array}{r}5 \\
0.125\end{array}$ & $\begin{array}{r}2 \\
0.05\end{array}$ & $\begin{array}{r}2 \\
0.05\end{array}$ & $\begin{array}{r}3 \\
0.075\end{array}$ \\
\hline 1975 & $\begin{array}{l}\text { Frequency } \\
\text { Prob. }\end{array}$ & $\begin{array}{r}16 \\
0.4\end{array}$ & $\begin{array}{r}12 \\
0.3\end{array}$ & $\begin{array}{r}4 \\
0.1\end{array}$ & $\begin{array}{r}4 \\
0.1\end{array}$ & $\begin{array}{r}1 \\
0.025\end{array}$ & $\begin{array}{r}3 \\
0.075\end{array}$ \\
\hline 1980 & $\begin{array}{l}\text { Frequency } \\
\text { Prob. }\end{array}$ & $\begin{array}{r}15 \\
0.375\end{array}$ & $\begin{array}{r}13 \\
0.325\end{array}$ & $\begin{array}{r}4 \\
0.1\end{array}$ & $\begin{array}{r}4 \\
0.1\end{array}$ & $\begin{array}{r}1 \\
0.025\end{array}$ & $\begin{array}{r}3 \\
0.075\end{array}$ \\
\hline 1985 & $\begin{array}{l}\text { Frequency } \\
\text { Prob. }\end{array}$ & $\begin{array}{r}17 \\
0.425\end{array}$ & $\begin{array}{r}12 \\
0.3\end{array}$ & $\begin{array}{r}3 \\
0.075\end{array}$ & $\begin{array}{r}3 \\
0.075 \\
\end{array}$ & $\begin{array}{r}2 \\
0.05\end{array}$ & $\begin{array}{r}3 \\
0.075 \\
\end{array}$ \\
\hline
\end{tabular}


Table 4: Average Transition Matrix for French Cities, 1876 - 1990

\begin{tabular}{|c|rrrrrr|}
\hline & \multicolumn{7}{|c|}{ Cell's Upper Endpoint } & & \\
\cline { 2 - 7 } & 0.3 & 0.5 & 0.75 & 1 & 2 & 20 \\
\hline 0.3 & 0.723 & 0.154 & 0 & 0 & 0 & 0 \\
0.5 & 0.254 & 0.796 & 0.118 & 0 & 0 & 0 \\
0.75 & 0.024 & 0.05 & 0.741 & 0.275 & 0 & 0 \\
1 & 0 & 0 & 0.14 & 0.692 & 0.083 & 0 \\
2 & 0 & 0 & 0 & 0.033 & 0.792 & 0.097 \\
20 & 0 & 0 & 0 & 0 & 0.125 & 0.903 \\
\hline
\end{tabular}

Table 6: Average of Ergodic Probabilities for French Cities

\begin{tabular}{|c|c|c|c|c|c|c|}
\hline & \multicolumn{6}{|c|}{ Cell's Upper Endpoint } \\
\hline & 0.3 & 0.5 & 0.75 & 1 & 2 & 20 \\
\hline Frequency & 8.229 & 14.898 & 7.956 & 4.095 & 1.677 & 2.145 \\
\hline Probability & 0.211 & 0.382 & 0.204 & 0.105 & 0.043 & 0.055 \\
\hline
\end{tabular}


Table 5: Average Transition Matrix for Japanese Cities, 1925 - 1985

\begin{tabular}{|c|rrrrrr|}
\hline & \multicolumn{7}{|c|}{ Cells Upper Endpoint } \\
\cline { 2 - 7 } & 0.3 & 0.5 & 0.75 & 1 & 2 & 20 \\
\hline 0.3 & 0.888 & 0.114 & 0 & 0 & 0 & 0 \\
0.5 & 0.112 & 0.855 & 0.152 & 0 & 0 & 0 \\
0.75 & 0 & 0.032 & 0.776 & 0.111 & 0 & 0 \\
1 & 0 & 0 & 0.072 & 0.826 & 0.069 & 0 \\
2 & 0 & 0 & 0 & 0.063 & 0.931 & 0 \\
20 & 0 & 0 & 0 & 0 & 0 & 1 \\
\hline
\end{tabular}

Table 7: Average of the Ergodic Probabilities for Japanese Cities

\begin{tabular}{|r|r|r|r|r|r|r|}
\hline & \multicolumn{7}{|c|}{ Cells Upper Endpoint } & & \\
& 0.3 & 0.5 & 0.75 & 1 & 2 & 20 \\
\hline \hline Frequency & 15.08 & 14.88 & 3.12 & 2.04 & 1.84 & 3 \\
\hline Probability & 0.377 & 0.372 & 0.078 & 0.051 & 0.046 & 0.075 \\
\hline
\end{tabular}


TABLE A 1: FRANCE AGGLOMERATIONS

SIZE IN THOUSANDS AND ANNUAL GROWTH RATE

\begin{tabular}{|c|c|c|c|c|c|c|c|c|}
\hline YEAR & & 1876 & & $\overline{1911}$ & & 1936 & & 1954 \\
\hline AMIENS & 68 & $0.96 \%$ & 95 & $0.17 \%$ & 99 & $0.00 \%$ & 99 & $2.00 \%$ \\
\hline ANGERS & 68 & $0.93 \%$ & 94 & $0.25 \%$ & 100 & $0.88 \%$ & 117 & $2.08 \%$ \\
\hline BESANCON & 56 & $0.15 \%$ & 59 & $0.45 \%$ & 66 & $0.64 \%$ & 74 & $3.96 \%$ \\
\hline BORDEAUX & 256 & $0.88 \%$ & 348 & $0.63 \%$ & 407 & $0.40 \%$ & 437 & $0.70 \%$ \\
\hline BREST & 87 & $1.06 \%$ & 126 & $-0.23 \%$ & 119 & $-0.39 \%$ & 111 & $2.85 \%$ \\
\hline BRUAY EN ARTOIS (BETHUNE) & 19 & $3.19 \%$ & 57 & $2.27 \%$ & 100 & $0.58 \%$ & 111 & $-0.46 \%$ \\
\hline CAEN & 46 & $0.35 \%$ & 52 & $1.58 \%$ & 77 & $0.74 \%$ & 88 & $3.84 \%$ \\
\hline CLERMONT-FERRAND & 49 & $1.22 \%$ & 75 & $1.83 \%$ & 118 & $0.87 \%$ & 138 & $2.18 \%$ \\
\hline DIJON & 52 & $1.27 \%$ & 81 & $1.04 \%$ & 105 & $0.97 \%$ & 125 & $2.81 \%$ \\
\hline DOUAN & 53 & $1.32 \%$ & 84 & $1.01 \%$ & 108 & $0.54 \%$ & 119 & $1.50 \%$ \\
\hline DUNKERQUE & 48 & $1.68 \%$ & 86 & $0.52 \%$ & 98 & $-0.11 \%$ & 96 & $2.83 \%$ \\
\hline GRENOBLE & 61 & $1.27 \%$ & 95 & $1.32 \%$ & 132 & $1.21 \%$ & 164 & $4.65 \%$ \\
\hline HAGONDAGE-BRIEY & 13 & $4.71 \%$ & 65 & $0.88 \%$ & 81 & $0.71 \%$ & 92 & $3.05 \%$ \\
\hline LE HAVRE & 106 & $1.24 \%$ & 163 & $1.00 \%$ & 209 & $-0.44 \%$ & 193 & $1.65 \%$ \\
\hline LE MANS & 53 & $0.88 \%$ & 72 & $0.81 \%$ & 88 & $1.60 \%$ & 117 & $2.54 \%$ \\
\hline LENS & 42 & $3.84 \%$ & 157 & $0.95 \%$ & 199 & $1.05 \%$ & 240 & $0.76 \%$ \\
\hline LILLE-ROUBA & 416 & $1.29 \%$ & 651 & $0.22 \%$ & 688 & $0.17 \%$ & 709 & $1.00 \%$ \\
\hline LIMOGES & 60 & $1.26 \%$ & 93 & $0.13 \%$ & 96 & $0.66 \%$ & 108 & $1.43 \%$ \\
\hline LYON & 416 & $1.01 \%$ & 591 & $0.65 \%$ & 695 & $0.35 \%$ & 740 & $2.23 \%$ \\
\hline MARSEILLE & 327 & $1.54 \%$ & 559 & $0.72 \%$ & 668 & $0.17 \%$ & 689 & $1.92 \%$ \\
\hline METZ & 61 & $1.75 \%$ & 112 & $0.21 \%$ & 118 & $0.45 \%$ & 128 & $2.34 \%$ \\
\hline MONTP & 56 . & $1.06 \%$ & 81 & $0.55 \%$ & 93 & $0.40 \%$ & 100 & $2.93 \%$ \\
\hline MULHOUSE & 83 & $1.44 \%$ & 137 & $0.17 \%$ & 143 & $0.08 \%$ & 145 & $1.55 \%$ \\
\hline NANCY & 83 & $1.76 \%$ & 153 & $0.52 \%$ & 174 & $0.37 \%$ & 186 & $1.71 \%$ \\
\hline NANTES & 151 & $0.86 \%$ & 204 & $0.65 \%$ & 240 & $1.00 \%$ & 287 & $1.68 \%$ \\
\hline NICE & 58 & $2.83 \%$ & 154 & $2.05 \%$ & 256 & $0.04 \%$ & 258 & $2.24 \%$ \\
\hline NIMES & 63 & $0.68 \%$ & 80 & $0.65 \%$ & 94 & $-0.30 \%$ & 89 & $1.84 \%$ \\
\hline ORLEANS & 63 & $0.89 \%$ & 86 & $0.36 \%$ & 94 & $0.56 \%$ & 104 & $2.63 \%$ \\
\hline PARIS & 2563 & $1.59 \%$ & 4446 & $0.88 \%$ & 5539 & $0.30 \%$ & 5842 & $1.25 \%$ \\
\hline REIMS & 85 & $0.99 \%$ & 120 & $0.10 \%$ & 123 & $0.22 \%$ & 128 & $1.66 \%$ \\
\hline RENNES & 58 & $0.89 \%$ & 79 & $0.99 \%$ & 101 & $1.32 \%$ & 128 & $2.75 \%$ \\
\hline ROUEN & 170 & $0.88 \%$ & 231 & $0.49 \%$ & 261 & $0.37 \%$ & 279 & $1.89 \%$ \\
\hline ST ETIENNE & 171 & $0.63 \%$ & 213 & $0.80 \%$ & 260 & $0.00 \%$ & 260 & $1.24 \%$ \\
\hline STRASBOURG & 117 & $1.87 \%$ & 224 & $0.49 \%$ & 253 & $0.24 \%$ & 264 & $1.65 \%$ \\
\hline THIONVILLE & 20 & $3.38 \%$ & 64 & $0.79 \%$ & 78 & $1.33 \%$ & 99 & $2.96 \%$ \\
\hline TTOULON & 90 & $1.21 \%$ & 137 & $1.32 \%$ & 190 & $-0.03 \%$ & 189 & $2.54 \%$ \\
\hline TOULOUSE & 134 & $0.36 \%$ & 152 & $1.42 \%$ & 216 & $1.29 \%$ & 272 & $2.45 \%$ \\
\hline TOURS & 62 & $1.13 \%$ & 92 & $0.97 \%$ & 117 & $0.50 \%$ & 128 & $2.26 \%$ \\
\hline VALENCIENNES & 77 & $1.08 \%$ & 112 & $0.75 \%$ & 135 & $0.62 \%$ & 151 & $1.57 \%$ \\
\hline
\end{tabular}

Source: INSEE, Annuarie statistic, Various issues 
TABLE A 1(Cont.): FRANCE AGGLOMERATIONS

SIZE IN THOUSANDS AND ANNUAL GROWTH RATE

\begin{tabular}{|c|c|c|c|c|c|}
\hline \begin{tabular}{|ll} 
CITIES & YEAR \\
\end{tabular} & & 1962 & & 1982 & 1990 \\
\hline AMIENS & 116 & $1.46 \%$ & 155 & $0.08 \%$ & 156 \\
\hline ANGERS & 138 & $1.82 \%$ & 198 & $0.62 \%$ & 208 \\
\hline BESANCON & 101 & $0.91 \%$ & 121 & $0.21 \%$ & 123 \\
\hline BORDEAUX & 462 & $1.71 \%$ & 648 & $0.85 \%$ & 699 \\
\hline BREST & 139 & $1.86 \%$ & 201 & $0.00 \%$ & 201 \\
\hline BRUAY EN ARTOIS (BETHUNE) & 107 & $4.50 \%$ & 258 & $-0.15 \%$ & 255 \\
\hline CAEN & 119 & $2.26 \%$ & 186 & $0.40 \%$ & 192 \\
\hline CLERMONT-FERRAND & 164 & $2.25 \%$ & 256 & $-0.10 \%$ & 254 \\
\hline DIJON & 156 & $1.71 \%$ & 219 & $0.61 \%$ & 230 \\
\hline DOUAI & 134 & $2.10 \%$ & 203 & $-0.19 \%$ & 200 \\
\hline DUNKERQUE & 120 & $2.43 \%$ & 194 & $-0.19 \%$ & 191 \\
\hline GRENOBLE & 236 & $2.62 \%$ & 396 & $0.28 \%$ & 405 \\
\hline HAGONDAGE-BRIEY & 117 & $0.13 \%$ & 120 & $-0.86 \%$ & 112 \\
\hline LE HAVRE & 220 & $0.74 \%$ & 255 & $-0.05 \%$ & 254 \\
\hline LE MANS & 143 & $1.46 \%$ & 191 & $-0.13 \%$ & 189 \\
\hline LENS & 255 & $1.27 \%$ & 328 & $-0.19 \%$ & 323 \\
\hline LILLE-ROUBAIX-TOURCOING & 768 & $1.04 \%$ & 944 & $0.20 \%$ & 959 \\
\hline LIMOGES & 121 & $1.77 \%$ & 172 & $-0.07 \%$ & 171 \\
\hline LYON & 883 & $1.63 \%$ & 1220 & $0.42 \%$ & 1262 \\
\hline MARSEILLE & 802 & $2.23 \%$ & 1246 & $-0.15 \%$ & 1231 \\
\hline METZ & 154 & $0.95 \%$ & 186 & $0.46 \%$ & 193 \\
\hline MONTPELLIER & 126 & $2.99 \%$ & 227 & $1.11 \%$ & 248 \\
\hline MULHOUSE & 164 & $1.48 \%$ & 220 & $0.23 \%$ & 224 \\
\hline NANCY & 213 & $2.15 \%$ & 326 & $0.11 \%$ & 329 \\
\hline NANTES & 328 & $1.79 \%$ & 468 & $0.70 \%$ & 495 \\
\hline NICE & 308 & $2.28 \%$ & 483 & $0.85 \%$ & 517 \\
\hline NIMES & 103 & $1.25 \%$ & 132 & $0.65 \%$ & 139 \\
\hline ORLEANS & 128 & $2.77 \%$ & 221 & $1.19 \%$ & 243 \\
\hline PARIS & 6454 & $1.64 \%$ & 8927 & $0.54 \%$ & 9319 \\
\hline REIMS & 146 & $1.59 \%$ & 200 & $0.37 \%$ & 206 \\
\hline RENNES & 159 & $1.95 \%$ & 234 & $0.58 \%$ & 245 \\
\hline ROUEN & 324 & $0.80 \%$ & 380 & $0.00 \%$ & 380 \\
\hline ST ETIENNE & 287 & $0.51 \%$ & 318 & $-0.20 \%$ & 313 \\
\hline STRASBOURG & 301 & $1.08 \%$ & 373 & $0.49 \%$ & 388 \\
\hline THIONVILLE & 125 & $0.46 \%$ & 137 & $-0.46 \%$ & 132 \\
\hline TOULON & 231 & $2.92 \%$ & 411 & $0.80 \%$ & 438 \\
\hline TOULOUSE & 330 & $2.74 \%$ & 567 & $1.72 \%$ & 650 \\
\hline TOURS & 153 & $2.90 \%$ & 271 & $0.50 \%$ & 282 \\
\hline VALENCIENNES & 171 & $3.68 \%$ & 352 & $-0.47 \%$ & 339 \\
\hline
\end{tabular}

Source: INSEE, Annuarie statistic, Various issues 
Table A2: Japanese Cities - Population in Thousands and Annual Growth Rate

\begin{tabular}{|c|c|c|c|c|c|c|c|c|}
\hline Year & \multicolumn{2}{|c|}{7825} & \multicolumn{2}{|l|}{1930} & \multicolumn{2}{|l|}{1835} & \multicolumn{2}{|l|}{1940} \\
\hline Tokyo(84) & 6,539 & $3.45 \%$ & 7.746 & $3.24 \%$ & 9,085 & $2.78 \%$ & 10.422 & $-2.90 \%$ \\
\hline Osaka(37) & 4,055 & $2.92 \%$ & 4,683 & $3.94 \%$ & 5,680 & $2.45 \%$ & 6,410 & $-5.07 \%$ \\
\hline Nagoya(19) & 1,404 & $2.67 \%$ & 1.602 & $4.27 \%$ & 1,875 & $1.55 \%$ & 2,132 & $-2.15 \%$ \\
\hline Kyolo (7) & 1,049 & $2.73 \%$ & 1,200 & $2.44 \%$ & 1,354 & $0.22 \%$ & 1,369 & $-0.40 \%$ \\
\hline Kitakyushu(5) & 740 & $2.59 \%$ & 840 & $2.95 \%$ & 972 & $3.55 \%$ & 1,158 & $-2.65 \%$ \\
\hline Hiroshima(3) & 561 & $3.13 \%$ & 655 & $2.57 \%$ & 743 & $1.42 \%$ & 797 & $.3 .24 \%$ \\
\hline Okayama/Kurashiki(2) & 496 & $0.73 \%$ & 515 & $1.91 \%$ & 566 & $0.06 \%$ & 568 & $2.13 \%$ \\
\hline Fukuoka(3) & 302 & $2.89 \%$ & 350 & $2.86 \%$ & 403 & $1.37 \%$ & 432 & $0.97 \%$ \\
\hline Maebashi/Takasaki(4) & 431 & $1.80 \%$ & 473 & $1.53 \%$ & 510 & $0.44 \%$ & 522 & $2.24 \%$ \\
\hline Shizuoka(3) & 371 & $1.24 \%$ & 408 & $1.85 \%$ & 447 & $1.20 \%$ & 475 & $1.29 \%$ \\
\hline Sapporo(2) & 220 & $3.08 \%$ & 256 & $2.86 \%$ & 294 & $1.10 \%$ & 311 & $3.06 \%$ \\
\hline Sendai(5) & 272 & $2.69 \%$ & 311 & $2.14 \%$ & 345 & $0.75 \%$ & 358 & $2.46 \%$ \\
\hline Hamamatsu(4) & 314 & $2.01 \%$ & 347 & $2.18 \%$ & 387 & $0.81 \%$ & 403 & $0.57 \%$ \\
\hline Nagasaki(2) & 318 & $1.19 \%$ & 337 & $0.61 \%$ & 348 & $1.47 \%$ & 374 & $0.08 \%$ \\
\hline Gifu(3) & 301 & $1.39 \%$ & 322 & $1.45 \%$ & 346 & $0.76 \%$ & 360 & $1.22 \%$ \\
\hline Himeji(2) & 290 & $1.03 \%$ & 306 & $1.22 \%$ & 325 & $1.98 \%$ & 359 & $1.95 \%$ \\
\hline Toyama(3) & 313 & $1.15 \%$ & 331 & $0.72 \%$ & 343 & $1.45 \%$ & 368 & $1.56 \%$ \\
\hline Niigata(3) & 25 & $1.71 \%$ & 281 & $1.11 \%$ & 297 & $1.62 \%$ & 321 & $2.55 \%$ \\
\hline Kumamoto(2) & 26 & 1.6 & 287 & $1.17 \%$ & 304 & $.0 .41 \%$ & 298 & $2.84 \%$ \\
\hline Numazu/Fuji(3) & 21 & $1.90 \%$ & 234 & $2.23 \%$ & 261 & $1.48 \%$ & 281 & $3.28 \%$ \\
\hline Mito/Hitachi(3) & 219 & $2.02 \%$ & 242 & $1.92 \%$ & 267 & $2.98 \%$ & 309 & $1.05 \%$ \\
\hline Nagano(3) & 268 & $1.11 \%$ & 283 & $0.27 \%$ & 287 & $0.02 \%$ & 287 & $3.35 \%$ \\
\hline Tokushima(3) & 277 & $0.80 \%$ & 280 & $0.83 \%$ & 302 & $-0.33 \%$ & 297 & $1.52 \%$ \\
\hline Takamatsu(2) & 254 & $1.27 \%$ & 271 & $0.86 \%$ & 283 & $-0.60 \%$ & 274 & $2.17 \%$ \\
\hline Wakayama(2) & 274 & $1.73 \%$ & 298 & $1.60 \%$ & 323 & $-0.21 \%$ & 319 & $.0 .47 \%$ \\
\hline Iwakj & 208 & $0.86 \%$ & 217 & $1.61 \%$ & 235 & $2.12 \%$ & 261 & $2.69 \%$ \\
\hline Toyohashi(2) & 211 & $2.17 \%$ & 235 & $0.55 \%$ & 241 & $0.66 \%$ & 249 & $2.00 \%$ \\
\hline Kanazawa(1) & 241 & $0.67 \%$ & 248 & $0.50 \%$ & 255 & $-0.04 \%$ & 255 & $2.12 \%$ \\
\hline Kagoshima & 20 & $1.42 \%$ & 217 & $1.41 \%$ & 233 & $0.59 \%$ & 240 & $0.08 \%$ \\
\hline Fukuyama(i) & 23 & $0.70 \%$ & 239 & $0.61 \%$ & 246 & $-0.29 \%$ & 243 & $2.52 \%$ \\
\hline Nagaoka(3) & 22 & $1.02 \%$ & 239 & $0.88 \%$ & 250 & $0.92 \%$ & 262 & $1.23 \%$ \\
\hline Matsuyama(2) & 20 & $1.07 \%$ & 216 & $-0.06 \%$ & 215 & $-0.12 \%$ & 214 & $2.81 \%$ \\
\hline Koriyama & 18 & $1.89 \%$ & 204 & $1.04 \%$ & 215 & $0.65 \%$ & 222 & $3.10 \%$ \\
\hline Fukui(2) & 22 & $1.12 \%$ & 233 & $1.83 \%$ & 258 & $0.09 \%$ & 257 & $0.27 \%$ \\
\hline Nara(3) & 19 & $0.53 \%$ & 203 & $1.77 \%$ & 221 & $-0.46 \%$ & 216 & $3.67 \%$ \\
\hline Yokkaichi(1) & 177 & $1.03 \%$ & 187 & $1.02 \%$ & 188 & $1.30 \%$ & 210 & $2.37 \%$ \\
\hline Hakodate & 183 & $3.67 \%$ & 219 & $1.42 \%$ & 236 & $-0.88 \%$ & 224 & $0.95 \%$ \\
\hline Sasebo & 161 & $3.00 \%$ & 187 & $4.63 \%$ & 234 & $1.82 \%$ & 256 & $-3.07 \%$ \\
\hline Kochi(2) & 18 & $1.65 \%$ & 203 & $0.20 \%$ & 205 & $-0.01 \%$ & 205 & $1.69 \%$ \\
\hline Asahikawa(1) & 150 & $2.06 \%$ & 166 & $0.71 \%$ & 172 & $-0.43 \%$ & 169 & $2.74 \%$ \\
\hline
\end{tabular}

Source: Population Census 
Table A2(Continue): Japanese Cities - Population in Thousands and Annual Growth Rate

\begin{tabular}{|c|c|c|c|c|c|c|c|c|}
\hline Cityname & \multicolumn{2}{|l|}{1847} & \multicolumn{2}{|l|}{1950} & \multicolumn{2}{|l|}{$\overline{1955}$} & \multicolumn{2}{|l|}{1960} \\
\hline Tokyo(84) & 8,484 & $6.90 \%$ & 10.365 & $4.24 \%$ & 12,756 & $3.23 \%$ & 14,956 & $3.68 \%$ \\
\hline Osaka(37) & 4,455 & $5.16 \%$ & 5,180 & $3.76 \%$ & 6,231 & $3.51 \%$ & 7.403 & $3.74 \%$ \\
\hline Nagoya(19) & 1,832 & $3.97 \%$ & 2,058 & $3.04 \%$ & 2,391 & $3.09 \%$ & 2,783 & $3.05 \%$ \\
\hline Kyoto $(7)$ & 1,330 & $2.41 \%$ & 1,429 & $1.48 \%$ & 1,538 & $1.12 \%$ & 1.627 & $1.73 \%$ \\
\hline Kitakyushu(5) & 958 & $4.78 \%$ & 1,103 & $2.91 \%$ & 1,273 & $2.01 \%$ & 1.407 & $0.73 \%$ \\
\hline Hiroshima(3) & 633 & $3.87 \%$ & 712 & $2.19 \%$ & 793 & $1.76 \%$ & 868 & $2.52 \%$ \\
\hline Okayama/Kurashiki(2) & 658 & $1.64 \%$ & 691 & $1.24 \%$ & 735 & $0.86 \%$ & 767 & $1.33 \%$ \\
\hline Fukuoka(3) & 462 & $5.33 \%$ & 540 & $3.80 \%$ & 654 & $2.82 \%$ & 751 & $2.72 \%$ \\
\hline Maebashi/Takasaki(4) & 610 & $1.08 \%$ & 630 & $0.43 \%$ & 643 & $0.06 \%$ & 645 & $1.18 \%$ \\
\hline Shizuoka(3) & 519 & $2.80 \%$ & 566 & $2.05 \%$ & 626 & $1.76 \%$ & 683 & $1.86 \%$ \\
\hline Sapporo(2) & 384 & $4.63 \%$ & 440 & $4.42 \%$ & 546 & $4.48 \%$ & 680 & $5.68 \%$ \\
\hline Sendai(5) & 425 & $4.02 \%$ & 478 & $1.74 \%$ & 521 & $1.97 \%$ & 575 & $2.38 \%$ \\
\hline Hamamatsu(4) & 419 & $2.56 \%$ & 452 & $2.00 \%$ & 499 & $1.35 \%$ & 534 & $1.45 \%$ \\
\hline Nagasaki(2) & 376 & $3.83 \%$ & 422 & $2.43 \%$ & 476 & $1.47 \%$ & 512 & $0.76 \%$ \\
\hline Gifu(3) & 382 & $2.18 \%$ & 417 & $2.14 \%$ & 464 & $1.88 \%$ & 512 & $2.37 \%$ \\
\hline Himeji(2) & 410 & $1.83 \%$ & 433 & $1.22 \%$ & 460 & $1.25 \%$ & 490 & $2.30 \%$ \\
\hline Toyama(3) & 411 & $1.98 \%$ & 436 & $0.83 \%$ & 454 & $0.77 \%$ & 472 & $0.68 \%$ \\
\hline Niigata(3) & 383 & $1.82 \%$ & 406 & $1.04 \%$ & 427 & $1.01 \%$ & 450 & $1.25 \%$ \\
\hline Kumamoto(2) & 362 & $2.07 \%$ & 385 & $2.09 \%$ & 427 & $1.07 \%$ & 450 & $1.25 \%$ \\
\hline Numazw/Fuji(3) & 353 & $1.46 \%$ & 368 & $1.61 \%$ & 398 & $1.86 \%$ & 437 & $2.16 \%$ \\
\hline Mito/Hitachi(3) & 332 & $1.62 \%$ & 349 & $1.57 \%$ & 377 & $2.05 \%$ & 417 & $1.89 \%$ \\
\hline Nagano(3) & 362 & $0.48 \%$ & 367 & $0.06 \%$ & 368 & $0.14 \%$ & 371 & $0.65 \%$ \\
\hline Tokushima(3) & 330 & $1.87 \%$ & 349 & $0.76 \%$ & 362 & $0.21 \%$ & 366 & $0.41 \%$ \\
\hline Takamatsu(2) & 318 & $2.51 \%$ & 344 & $0.86 \%$ & 360 & $0.37 \%$ & 367 & $0.58 \%$ \\
\hline Wakayama(2) & 308 & $2.13 \%$ & 329 & $1.48 \%$ & 354 & $1.03 \%$ & 373 & $2.16 \%$ \\
\hline Iwaki & 314 & $2.74 \%$ & 340 & $0.65 \%$ & 351 & $-0.33 \%$ & 346 & $-0.69 \%$ \\
\hline Toyohashi(2) & 287 & $2.55 \%$ & 309 & $1.75 \%$ & 337 & $1.13 \%$ & 357 & $2.07 \%$ \\
\hline Kanazawa(1) & 295 & $1.98 \%$ & 313 & $1.01 \%$ & 328 & $0.78 \%$ & 342 & $1.34 \%$ \\
\hline Kagoshima & 242 & $3.72 \%$ & 270 & $3.10 \%$ & 314 & $1.28 \%$ & 335 & $2.09 \%$ \\
\hline Fukuyama(1) & 289 & $0.83 \%$ & 296 & $0.62 \%$ & 308 & $0.85 \%$ & 319 & $1.19 \%$ \\
\hline Nagaoka(3) & 285 & $1,44 \%$ & 298 & $0.48 \%$ & 305 & $0.32 \%$ & 310 & $0.48 \%$ \\
\hline Maisuyama(2) & 260 & $2.25 \%$ & 278 & $1.66 \%$ & 302 & $1.26 \%$ & 321 & $1.55 \%$ \\
\hline Koriyama & 274 & $1.36 \%$ & 286 & $0.77 \%$ & 297 & $0.38 \%$ & 302 & $0.55 \%$ \\
\hline Fukui(2) & 262 & $2.86 \%$ & 285 & $0.52 \%$ & 293 & $0.86 \%$ & 306 & $0.82 \%$ \\
\hline Nara(3) & 278 & $-1.32 \%$ & 267 & $0.75 \%$ & 277 & $0.38 \%$ & 283 & $2.63 \%$ \\
\hline Yokkaichi(1) & 247 & $1.68 \%$ & 260 & $1.00 \%$ & 273 & $1.42 \%$ & 293 & $2.14 \%$ \\
\hline Hakodate & 240 & $1.80 \%$ & 253 & $1.17 \%$ & 268 & $0.24 \%$ & 271 & $0.72 \%$ \\
\hline Sasebo & 206 & $3.38 \%$ & 228 & $2.99 \%$ & 264 & $-0.11 \%$ & 262 & $-1.20 \%$ \\
\hline Kochi(2) & 231 & $2.10 \%$ & 246 & $1.34 \%$ & 263 & $0.88 \%$ & 274 & $1.44 \%$ \\
\hline Asahikawa(1) & 204 & $3.37 \%$ & 225 & $2.69 \%$ & 257 & $1.82 \%$ & 281 & $2.08 \%$ \\
\hline
\end{tabular}

Source: Population Census 
Table A2(Continue): Japanese Cities - Population in Thousands and Annual Growth Rate

\begin{tabular}{|c|c|c|c|c|c|c|c|c|c|}
\hline Year & $\overline{1965}$ & & $\overline{970}$ & & 1975 & & 7980 & & 1985 \\
\hline Tokyo(84) & 17,915 & $3.09 \%$ & 20,856 & $1.72 \%$ & 22,710 & $0.87 \%$ & 23.718 & $2.26 \%$ & 26,517 \\
\hline Osaka(37) & 8,893 & $2.57 \%$ & 10,098 & $1.51 \%$ & 10,883 & $0.36 \%$ & 11.079 & $0.41 \%$ & 11,307 \\
\hline Nagoya(19) & 3,234 & $2.12 \%$ & 3,593 & $1.62 \%$ & 3,894 & $0.78 \%$ & 4,049 & $0.60 \%$ & 4,171 \\
\hline Kyoto(n) & 1,773 & $1.88 \%$ & 1,947 & $1.73 \%$ & 2,121 & $1.02 \%$ & 2,231 & $0.66 \%$ & 2,305 \\
\hline Kitakyushu(5) & 1,459 & $0.12 \%$ & 1,467 & $0.78 \%$ & 1.525 & $0.50 \%$ & 1.564 & $0.04 \%$ & 1,567 \\
\hline Hiroshima(3) & 881 & $1.96 \%$ & 1,081 & $2.08 \%$ & 1,197 & $0.85 \%$ & 1,249 & $2.22 \%$ & 1,394 \\
\hline OkayamaKurashiki(2) & 819 & $2.60 \%$ & 932 & $2.06 \%$ & 1,032 & $0.85 \%$ & 1,076 & $0.69 \%$ & 1,114 \\
\hline Fukuoka(3) & 860 & $2.78 \%$ & 986 & $3.25 \%$ & 1,157 & $1.98 \%$ & 1,277 & $8.71 \%$ & 1,938 \\
\hline MaebashivTakasaki(4) & 684 & $1.45 \%$ & 736 & $1.30 \%$ & 784 & $0.95 \%$ & 822 & $0.77 \%$ & 854 \\
\hline Shizuoka(3) & 749 & $1.64 \%$ & 813 & $1.47 \%$ & 874 & $0.74 \%$ & 808 & $0.51 \%$ & 931 \\
\hline Sapporo(2) & 896 & $4.34 \%$ & 1.108 & $4.15 \%$ & 1,358 & $2.43 \%$ & 1,531 & $1.89 \%$ & 1,682 \\
\hline Sendai(5) & 647 & $2.85 \%$ & 744 & $3.14 \%$ & 869 & $2.00 \%$ & 859 & $1.40 \%$ & 1,028 \\
\hline Hamamatsu(4) & 574 & $1.73 \%$ & 625 & $1.71 \%$ & 680 & $1.23 \%$ & 723 & $1.08 \%$ & 763 \\
\hline $\operatorname{Nagasakj(2)}$ & 532 & $0.63 \%$ & 549 & $1.26 \%$ & 584 & $0.40 \%$ & 596 & $0.36 \%$ & 607 \\
\hline Gifu(3) & 575 & $1.43 \%$ & 618 & $1.19 \%$ & 656 & $0.43 \%$ & 670 & $0.35 \%$ & 682 \\
\hline Himeji(2) & 549 & $2.39 \%$ & 618 & $2.43 \%$ & 696 & $1.33 \%$ & 744 & $0.73 \%$ & 772 \\
\hline Toyama(3) & 488 & $0.67 \%$ & 505 & $1.17 \%$ & 535 & $0.70 \%$ & 554 & $0.31 \%$ & 562 \\
\hline Niigata(3) & 478 & $1.12 \%$ & 506 & $1.76 \%$ & 552 & $1.52 \%$ & 595 & $0.76 \%$ & 618 \\
\hline Kumamoto(2) & 479 & $1.26 \%$ & 510 & $1.44 \%$ & 548 & $1.39 \%$ & 587 & $1.03 \%$ & 618 \\
\hline Numazu/Fuji(3) & 487 & $1.75 \%$ & 531 & $1.69 \%$ & 577 & $0.62 \%$ & 595 & $0.79 \%$ & 619 \\
\hline Mito/Hitachi(3) & 458 & $1.86 \%$ & 502 & $1.79 \%$ & 549 & $1.18 \%$ & 582 & $0.86 \%$ & 607 \\
\hline Nagano(3) & 383 & $0.95 \%$ & 401 & $1.31 \%$ & 428 & $1.08 \%$ & 452 & $0.70 \%$ & 468 \\
\hline Tokushima(3) & 374 & $0.49 \%$ & 383 & $1.06 \%$ & 404 & $0.67 \%$ & 418 & $0.44 \%$ & 427 \\
\hline Takamatsu(2) & 378 & $1.03 \%$ & 398 & $1.68 \%$ & 432 & $0.98 \%$ & 454 & $0.59 \%$ & 467 \\
\hline Wakayama(2) & 415 & $1.78 \%$ & 453 & $1.08 \%$ & 478 & $0.46 \%$ & 489 & $-0.06 \%$ & 488 \\
\hline Iwakj & 334 & $-0.41 \%$ & 327 & $0.19 \%$ & 330 & $0.71 \%$ & 342 & $0.49 \%$ & 351 \\
\hline Toyohashi(2) & 395 & $1.59 \%$ & 427 & $1.84 \%$ & 468 & $1.03 \%$ & 493 & $0.90 \%$ & 515 \\
\hline Kanazawa(1) & 365 & $1.44 \%$ & 392 & $1.91 \%$ & 431 & $1.35 \%$ & 461 & $0.92 \%$ & 483 \\
\hline Kagoshima & 371 & $1.68 \%$ & 403 & $2.52 \%$ & 457 & $2.04 \%$ & 505 & $0.98 \%$ & 531 \\
\hline Fukuyama(1) & 338 & $2.85 \%$ & 389 & $2.14 \%$ & 433 & $0.70 \%$ & 448 & $0.57 \%$ & 461 \\
\hline Nagaoka(3) & 317 & $0.53 \%$ & 326 & $0.80 \%$ & 339 & $0.78 \%$ & 352 & $0.25 \%$ & 357 \\
\hline Matsuyama(2) & 347 & $1.78 \%$ & 379 & $2.30 \%$ & 425 & $1.70 \%$ & 462 & $1.07 \%$ & 487 \\
\hline Koriyama & 311 & $1.11 \%$ & 329 & $1.45 \%$ & 353 & $1.33 \%$ & 377 & $0.92 \%$ & 395 \\
\hline Fukui(2) & 318 & $0.71 \%$ & 330 & $1.41 \%$ & 354 & $0.78 \%$ & 368 & $0.71 \%$ & 381 \\
\hline Nara(3) & 322 & $4.08 \%$ & 393 & $3.67 \%$ & 470 & $2.28 \%$ & 527 & $1.55 \%$ & 569 \\
\hline Yokkaichi(1) & 326 & $1.48 \%$ & 350 & $2.10 \%$ & 389 & $1.15 \%$ & 412 & $0.78 \%$ & 428 \\
\hline Hakodate & 281 & $0.79 \%$ & 292 & $1.02 \%$ & 307 & $0.81 \%$ & 320 & $-0.06 \%$ & 319 \\
\hline Sasebo & 247 & $0.07 \%$ & 248 & $0.23 \%$ & 251 & $0.04 \%$ & 251 & $-0.04 \%$ & 251 \\
\hline Kochi(2) & 295 & $1.60 \%$ & 319 & $2.12 \%$ & 354 & $1.26 \%$ & 377 & $0.76 \%$ & 392 \\
\hline Asahikawa(1) & 312 & $1.48 \%$ & 336 & $1.22 \%$ & 357 & $1.71 \%$ & 388 & $0.48 \%$ & 397 \\
\hline
\end{tabular}

Source: Population Census 
Table A3: Lorenz Curves for French Data

\begin{tabular}{|c|c|c|c|c|c|c|}
\hline 1876 & 1941 & 1936 & 1954 & 1962 & 1982 & 1990 \\
\hline 0.0020 & 0.0050 & 0.0052 & 0.0054 & 0.0065 & 055 & \\
\hline 0.0050 & 0.0104 & 0.0112 & 0.0119 & 0.0132 & 0110 & 0104 \\
\hline 0.0080 & 0.0160 & 0.0174 & 0.0185 & 0.0201 & 0170 & 0.0162 \\
\hline 0.0146 & 0.0221 & 0.0237 & 0.0252 & 0.0275 & 0.0232 & 0.0223 \\
\hline 0.0217 & 0.0283 & 0.0306 & 0.0323 & 0.0351 & 0.0303 & 0.0292 \\
\hline 0.0291 & 0.0352 & 0.0379 & 0.0395 & 0.0428 & 0.0381 & 0.0367 \\
\hline 0.0367 & 0.0424 & 0.0453 & 0.0468 & 0.0505 & 0.0466 & 0.0450 \\
\hline 0.0447 & 0.0499 & 0.0527 & 0.0542 & 0.0583 & .0551 & 0535 \\
\hline 0.0529 & 0.0575 & 0.0602 & 0.0618 & 0.0664 & .0638 & .0619 \\
\hline 0.0611 & 0.0653 & 0679 & 0698 & 0.0745 & .0726 & 0.0704 \\
\hline 0.0698 & 30 & 757 & 0.0779 & 0.0837 & 0.0817 & 0.0792 \\
\hline 0.0785 & 0.0810 & 0.0835 & 0.0861 & 0.0914 & 0.0908 & 0.0881 \\
\hline 0.0875 & 0.0892 & 0.0914 & 0.0947 & 0.1003 & 0.0999 & 0.0972 \\
\hline 0.0964 & 0.0974 & 0.0993 & 0.1033 & 0.1092 & 0.1092 & 1063 \\
\hline 0.1057 & 0.1062 & 0.1076 & 0.1120 & 1185 & 192 & 62 \\
\hline 0.1152 & 0.1151 & 1160 & 1212 & 1279 & 92 & 63 \\
\hline 0.1246 & 240 & 252 & 1306 & 0.1378 & 0.1393 & 70 \\
\hline 0.1342 & 331 & 34 & 0.1400 & 77 & 0.1496 & 0.1478 \\
\hline 0.1439 & 422 & 37 & 1494 & 0.1577 & 0.1603 & 0.1588 \\
\hline 0.1537 & 529 & 0.1531 & 0.1589 & 0.1680 & 0.1719 & 0.1699 \\
\hline 0.1642 & 0.1635 & 0.1627 & 0.1690 & 0.1786 & 0.1836 & 0.1811 \\
\hline 0.1747 & 0.1750 & 0.1731 & 0.1797 & 0.1892 & 0.1953 & 0.1924 \\
\hline 0.1867 & 870 & 0.1837 & 0.1908 & 0.2002 & 0.2077 & 0.2048 \\
\hline 0.1995 & 0.2001 & 0.1949 & 0.2028 & 0.2139 & 0.2222 & 186 \\
\hline 0.2124 & 0.2132 & 0.2086 & 65 & 0.2281 & 0.2370 & 0.2328 \\
\hline 0.2255 & 77 & 0.2235 & 304 & 0.2430 & 0.2520 & 0.2473 \\
\hline 0.2390 & 0.2423 & 0.2391 & 0.2446 & 0.2582 & 0.2680 & 0.2623 \\
\hline 0.2529 & 0.2570 & 0.2555 & 0.2622 & 0.2747 & 0.2850 & 0.2790 \\
\hline 0.2693 & 0.2719 & 0.2725 & 0.2812 & 0.2932 & 0.3023 & 0.2961 \\
\hline 0.2874 & 0.2875 & 0.2913 & 0.3003 & 0.3026 & 0.3204 & 0.3139 \\
\hline 0.3082 & 0.3070 & 0.3112 & 0.3197 & 0.3325 & 0.3391 & 0.333 \\
\hline 0.3315 & 0.3273 & 0.3313 & 0.3397 & 0.3533 & 0.3604 & 0.355 \\
\hline 0.3578 & 0.3487 & 0.3517 & 0.3602 & 0.3745 & 0.3824 & 0.3778 \\
\hline 0.3843 & 0.3707 & 0.3722 & 0.3813 & 0.3958 & 0.4083 & 0.4065 \\
\hline 0.4239 & 0.4039 & 0.4041 & 0.4134 & 0.4256 & 0.4378 & 0.4373 \\
\hline 0.4745 & 0.4573 & 0.4566 & 0.4641 & 0.4751 & 0.4808 & 0.4795 \\
\hline 0.5389 & 0.5136 & 0.5106 & 0.5162 & 0.5268 & 0.5364 & 0.5338 \\
\hline 0.6033 & 0.5758 & 0.5652 & 0.5706 & 0.5838 & 0.5932 & 0.5894 \\
\hline & & & & & & \\
\hline
\end{tabular}


Table A4: Lorenz Curves for Japanese Data

\begin{tabular}{|c|c|c|c|c|c|c|}
\hline 1925 & 1930 & 1935 & 1940 & 1947 & 1950 & 1955 \\
\hline 0.0065 & 0.0064 & 0.0058 & 0.0052 & 0.0069 & 0.0066 & 0.0067 \\
\hline 0.0135 & 0.0135 & 0.0123 & 0.0114 & 0.0139 & 0.0132 & 0.0135 \\
\hline 0.0213 & 0.0207 & 0.0192 & 0.0179 & 0.0218 & 0.0204 & 0.0203 \\
\hline 0.0292 & 0.0285 & 0.0264 & 0.0244 & 0.0299 & 0.0278 & 0.0273 \\
\hline 0.0373 & 0.0363 & 0.0336 & 0.0310 & 0.0381 & 0.0354 & 0.0343 \\
\hline 154 & 0.0441 & 0.0410 & 0.0378 & 0.0465 & 0.0432 & 0.0415 \\
\hline 0.0540 & 0.0524 & 0.0488 & 0.0446 & 0.0554 & 0.0511 & 491 \\
\hline 0.0628 & 0.0607 & 0.0567 & 0.0520 & 0.0643 & 0.0592 & 568 \\
\hline 0.0717 & 0.0690 & 0.0645 & 0.0594 & 0.0736 & 0.0676 & 346 \\
\hline 0.0808 & 0.0774 & 0.0724 & 0.0671 & 0.0830 & 0.0759 & 0.0725 \\
\hline 0.0899 & 0.0863 & 0.0805 & 0.0749 & 0.0927 & 0.0846 & 0.0805 \\
\hline 0.0992 & 0.0953 & 0.0888 & 0.0827 & 0.1025 & 0.0933 & 0.0886 \\
\hline 0.1087 & 0.1043 & 0.0971 & 0.0906 & 0.1123 & 0.1023 & 0.0971 \\
\hline 0.1183 & 0.1135 & 0.1057 & 0.0985 & 0.1223 & 0.1115 & 0.1059 \\
\hline 79 & 0.1227 & 0.1143 & 0.1065 & 0.1328 & 0.1211 & 0.1150 \\
\hline 78 & 0.1319 & 0.1230 & 0.1149 & 0.1435 & 0.1310 & 0.1242 \\
\hline 0.1478 & 0.1415 & 0.1319 & 0.1236 & 0.1543 & 0.1411 & 0. \\
\hline 0.1583 & 0.1513 & 0.1414 & 0.1323 & 0.1655 & 0.1513 & 129 \\
\hline 0.1693 & 0.1617 & 0.1510 & 0.1414 & 0.1768 & 0.1615 & 0.1524 \\
\hline 0.1805 & 0.1724 & 0.1609 & 0.1505 & 0.1888 & 0.1722 & 0.1622 \\
\hline 0.1920 & 0.1833 & 0.1708 & 0.1600 & 0.2011 & 0.1830 & 0.1725 \\
\hline 37 & 0.1943 & 0.1809 & 0.1695 & 0.2134 & 0.1942 & 0.1836 \\
\hline 0.2 & 0.2054 & 0.1911 & 0.1793 & 0.2262 & 0.2061 & 0.1947 \\
\hline 0.2274 & 0.2168 & 0.2019 & 0.1891 & 0.2392 & 0.2183 & 065 \\
\hline 0.2395 & 0.2285 & 0.2128 & 0.2001 & 0.2523 & 0.2306 & 0.2 \\
\hline 0.2521 & 0.2404 & 0.2243 & 0.2110 & 0.2656 & 0.2433 & 0.2304 \\
\hline 0.2652 & 0.2528 & 0.2358 & 0.2220 & 0.2795 & 0.2560 & 0.2428 \\
\hline 0.2783 & 0.2655 & 0.2474 & 0.2333 & 0.2935 & 0.2689 & 0.2557 \\
\hline 0. & 0.2784 & 0.2591 & 0.2448 & 0.3078 & 0.2821 & 0.2692 \\
\hline 0.3056 & 0.2918 & 0.2721 & 0.2571 & 0.3222 & 0.2961 & 0.2834 \\
\hline 0.3195 & 0.3052 & 0.2856 & 0.2703 & 0.3379 & 0.3119 & 0.2996 \\
\hline 0.3356 & 0.3208 & 0.3005 & 0.2848 & 0.3556 & 0.3284 & 0.3163 \\
\hline 0.3543 & 0.3390 & 0.3176 & 0.3008 & 0.3763 & 0.3486 & 0.3333 \\
\hline 0.3759 & 0.3587 & 0.3366 & 0.3181 & 0.3978 & 0.3695 & 0.3523 \\
\hline 0.4003 & 0.3838 & 0.3615 & 0.3425 & 0.4202 & 0.4017 & 0.3729 \\
\hline 0.4325 & 0.4160 & 0.3940 & 0.3780 & 0.4528 & 0.4435 & 0.4059 \\
\hline 0.4781 & 0.4620 & 0.4394 & 0.4198 & 0.4980 & 0.4853 & 0.4458 \\
\hline 0.5392 & 0.5235 & 0.5055 & 0.4851 & 0.5602 & 0.5455 & 0.5078 \\
\hline 0.7156 & 0.7030 & 0.6958 & 0.6812 & 0.7116 & 0.6969 & 0.6693 \\
\hline & & & & & & \\
\hline
\end{tabular}


Table A4(Continue): Data for Japanese City's Lorentz Curves

\begin{tabular}{|c|c|c|c|c|c|}
\hline 1960 & 1965 & 1970 & 1975 & 1980 & 1985 \\
\hline 0.0060 & 0.0048 & 0.0042 & 0.0041 & 0.0039 & 0.0036 \\
\hline 123 & 0.0103 & 0.0092 & 0091 & 0.0089 & 083 \\
\hline 186 & 0.0160 & 0.0148 & 0145 & 0.0143 & 134 \\
\hline 0.0250 & 0.0221 & 0.0204 & 0.0200 & 0.0198 & .0186 \\
\hline 0.0315 & 0.0281 & 0.0260 & 0.0258 & 0.0255 & .0241 \\
\hline 0.0383 & 0.0343 & 0.0317 & 0.0316 & 0.0314 & 0.0 \\
\hline 0.0452 & 0.0406 & 0.0374 & 0.0374 & 0.0373 & \\
\hline 0.0523 & 0.0469 & 0.0434 & 0.0432 & & \\
\hline 0.0594 & 0.0534 & 0.0499 & 0.0495 & 198 & 475 \\
\hline 0.0667 & 0.0600 & 0.0565 & 0.0561 & 0.0563 & 0.0537 \\
\hline 0.0741 & 0.0668 & 0.0631 & 0.0631 & 0.0633 & 0.0604 \\
\hline 0.0818 & 0.0739 & 0.0698 & 0.0701 & 0.0704 & 0.0672 \\
\hline 0.0896 & 0.0811 & 0.0766 & 0.0 & 0.0775 & 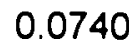 \\
\hline 0.0976 & 0.0884 & 0.0834 & 0.0 & 47 & 10 \\
\hline 0.1058 & 0.0958 & 0.0902 & 0.0 & & \\
\hline 42 & 32 & 0.0 & & & \\
\hline 27 & 0. & 0.1 & & & \\
\hline 0.1312 & 0.1190 & 0.1122 & 0.1 & 0.1 & 04 \\
\hline 0.1397 & 0.1279 & 0.1208 & 0.1218 & 0.1234 & \\
\hline 0.1493 & 0.1372 & 0.1294 & 0.1 & 0. & 268 \\
\hline 0.1594 & 0.1465 & 0.1381 & 0.1 & 0. & 356 \\
\hline 697 & 60 & 0.1468 & 35 & 03 & \\
\hline 01 & 55 & 0. & & & \\
\hline 0. & 59 & 0.1653 & 0.1 & 89 & 524 \\
\hline 0.2022 & 0.1866 & 0.1759 & 0.1764 & 82 & 714 \\
\hline 0.2140 & 0.1977 & 0.1864 & 0.1871 & 0.1887 & 813 \\
\hline 0.2257 & 0.2090 & 0.1971 & 0.1982 & 0.2000 & 924 \\
\hline 0.2380 & 0.2215 & 0.2097 & 0.2096 & 0.2116 & 0.2036 \\
\hline 0.2512 & 0.2349 & 0.2225 & 0.2224 & 244 & \\
\hline 0.2661 & 0.2495 & 0.2364 & 0.2366 & & \\
\hline 17 & 0.2654 & 0.2523 & 0.2509 & & 445 \\
\hline 74 & 0.2 & 0.2692 & 0.2 & 04 & 607 \\
\hline 47 & 0.2 & 0.2 & 0.2866 & 0.2 & 810 \\
\hline 0.3323 & 0.3187 & 0.3067 & 0.3062 & 0.3099 & 0.3037 \\
\hline 0.3522 & 0.3471 & 0.3318 & 0.3284 & 0.3338 & 0.3282 \\
\hline 0.3845 & 0.3805 & 0.3651 & 0.3533 & 0.3582 & 0.3563 \\
\hline 0.4220 & 0.4150 & 0.4088 & 0.3879 & 0.3931 & 0.3898 \\
\hline & 0.4780 & 0.4703 & 0.4515 & 0.4563 & 0.4504 \\
\hline 0.6562 & 0.6512 & 0.6431 & 0.6292 & 0.6294 & 0.6147 \\
\hline 1 & & & & & \\
\hline
\end{tabular}


Table A5: French Wage Index

\begin{tabular}{|c|c|c|}
\hline \multirow{2}{*}{\begin{tabular}{|lr} 
City & Year \\
\end{tabular}} & \multirow[t]{2}{*}{1982} & \multirow[t]{2}{*}{1990} \\
\hline & & \\
\hline PARIS & 124.2 & 127.3 \\
\hline MARSEILLE & 103.1 & 105.7 \\
\hline LYON & 105.2 & 100.1 \\
\hline LILLE-ROUBAIX-TOURCOING & 98.1 & 96.0 \\
\hline BORDEAUX & 100.9 & 99.5 \\
\hline TOULOUSE & 100.3 & 101.2 \\
\hline NICE & 96.4 & 97.9 \\
\hline NANTES & 100.7 & 102.4 \\
\hline TOULON & 90.5 & 88.8 \\
\hline GRENOBLE & 104.7 & 108.9 \\
\hline ROUEN & 100.1 & 100.9 \\
\hline STRASBOURG & 99.4 & 95.3 \\
\hline NALENCIENNES & 89.9 & 84.7 \\
\hline LENS & 97.1 & 97.6 \\
\hline NANCY & 100.5 & 86.8 \\
\hline ST ETIENNE & 95.3 & 95.6 \\
\hline TOURS & 93.9 & 92.3 \\
\hline BRUAY EN ARTOIS (BETHUNE) & 85.7 & 82.1 \\
\hline CLERMONT-FERRAND & 97.6 & 96.7 \\
\hline LE HAVRE & 104.9 & 97.7 \\
\hline RENNES & 99.2 & 101.3 \\
\hline MONTPELLIER & 103.3 & 96.2 \\
\hline ORLEANS & 100.8 & 100.8 \\
\hline MULHOUSE & 99.6 & 93.9 \\
\hline DIJON & 95.2 & 95.9 \\
\hline DOUAI & 99.7 & 97.8 \\
\hline BREST & 94.3 & 92.0 \\
\hline |REIMS & 94.3 & 95.6 \\
\hline ANGERS & 92.8 & 95.6 \\
\hline DUNKERQUE & 108.4 & 92.6 \\
\hline LE MANS & 95.9 & 91.5 \\
\hline METZ & 93.4 & 99.4 \\
\hline CAEN & 94.8 & 92.6 \\
\hline LIMOGES & 95.1 & 91.9 \\
\hline AMIENS & 91.8 & 89.7 \\
\hline THIONVILLE & 100.1 & 87.3 \\
\hline NIMES & 89.4 & 94.3 \\
\hline BESANCON & 90.5 & 60.6 \\
\hline HAGONDAGE-BRIEY & 99.0 & 91.2 \\
\hline
\end{tabular}




\author{
Data Appendix \\ Japanese Agglomerations
}

\title{
Akiko Tamura
}

The data are based on the population census taken every 5 years from 1925 to 1985 (except 1947 instead of 1945), calculated by the city's legal border in 1980, by the statistics Bureau of the Management and Coordination Agency. In 1980 there were 650 cities in Japan.

We created about 60 agglomerations according to the following procedures:

First, we took the largest 100 cities in 1955, and then aggregated the surrounding small cities' populations with that of each large city. The basic criteria for selection are

1) Tokyo -- within a radius of $45 \mathrm{kilometers} \mathrm{from} \mathrm{Shinjuku.}$ Tokyo includes 84 cities other than 23 special districts. Most of the cities in Kanagawa, Chiba, and Saitama prefectures are included in Tokyo.

2) Osaka, Nagoya --- within a radius of 30 kilometers.

3) The 6 "Designated Cities": Sapporo, Sendai, Kyoto, Hiroshima, Kitakyushu, Fukuoka -- within a radius of $25 \mathrm{kilometers.}$ (In 1993, 12 cities were "Designated Cities." These cities are given 17 categories of administrative responsibilities otherwise assigned to the prefectural government, such as welfare, health, and city planning. Of these 12 we separate Osaka and Nagoya because of their size. We have assigned Yokohama, Kawasaki, and chiba to the Tokyo agglomeration and Kobe to Osaka.

4) Other cities --- within a radius of 20 kilometers

The number in the parenthesis following the city name shows how many small cities are included in its metropolitan area other than the city itself. In some cases, two similarly-sized cities are within $40 \mathrm{Km}$ circle. We then call the agglomeration by the name of both cities, for example, Maebashi/Takasaki, Numazu/Fuji, and Okayama/Kurashiki

Some exceptions occur where indicated by geographical and traffic conditions. For example, for Tokyo(with a $90 \mathrm{Km}$ diameter), we exclude Kisarazu since it is separated from Tokyo by Tokyo Bay, but we include Yokosuka, which is $47 \mathrm{Km}$ from Shinjuku but connected by a fast express line to Tokyo.

If circles overlap, then the small cities in the overlapping area are aggregated with the nearer city unless: i) the sizes of two central cites' are significantly different, in which case the city is aggregated with the larger of the two central cities (For example, in the case of Osaka and Kyoto, the small cities in the 
overlapping area are in Osaka; ii) the prefectural border crosses the overlapping area, in which case the small cities are aggregated with the central city in same prefecture. 